\title{
Evaluation of remote-sensing techniques to measure decadal-scale changes of Hofsjökull ice cap, Iceland
}

\author{
D. K. Hall, ${ }^{1}$ R. S. Williams, JR, ${ }^{2}$ J. S. Barton, ${ }^{3}$ O. SigurĐsson, ${ }^{4}$ L. G. Smith, ${ }^{5}$ J. B. Garvin ${ }^{6}$ \\ ${ }^{1}$ Hydrological Sciences Branch, Code 974, NASA/Goddard Space Flight Center, Greenbelt, Maryland 20771, U.S.A. \\ ${ }^{2}$ U.S. Geological Survey, Woods Hole Field Center, Woods Hole, Massachusetts 02543-1598, U.S.A. \\ ${ }^{3}$ General Sciences Corporation, Beltsville, Maryland 20705, U.S.A. \\ ${ }^{4}$ National Energy Authority, Grensásvegi 9, IS-108 Reykjavik, Iceland \\ ${ }^{5}$ Department of Geography, University of California, Los Angeles, California 90095-1524, U.S.A. \\ ${ }^{6}$ Geodynamics Branch, Code 921, NASA/Goddard Space Flight Center, Greenbelt, Maryland 20771, U.S.A.
}

\begin{abstract}
Dynamic surficial changes and changes in the position of the firn line and the areal extent of Hofsjökull ice cap, Iceland, were studied through analysis of a time series (1973-98) of synthetic-aperture radar (SAR) and Landsat data. A digital elevation model of Hofsjökull, which was constructed using SAR interferometry, was used to plot the SAR backscatter coefficient $\left(\sigma^{\circ}\right)$ vs elevation and air temperature along transects across the ice cap. Seasonal and daily $\sigma^{\circ}$ patterns are caused by freezing or thawing of the ice-cap surface, and abrupt changes in $\sigma^{\circ}$ are noted when the air temperature ranges from $\sim-5^{\circ}$ to $0^{\circ} \mathrm{C}$. Late-summer $1997 \sigma^{\circ}$ (SAR) and reflectance (Landsat) boundaries agree and appear to be coincident with the firn line and a SAR $\sigma^{\circ}$ boundary that can be seen in the January 1998 SAR image. In January 1994 through 1998, the elevation of this $\sigma^{\circ}$ boundary on the ice cap was quite stable, ranging from 1000 to $1300 \mathrm{~m}$, while the equilibrium-line altitude, as measured on the ground, varied considerably. Thus the equilibrium line may be obscured by firn from previous years. Techniques are established to measure long-term changes in the elevation of the firn line and changes in the position of the ice margin.
\end{abstract}

\section{INTRODUGTION}

Glaciers in Iceland began retreating in the late 19th century, following the end of the "Little Ice Age". An acceleration of the retreat began after about 1930, and continued until about 1960, after which the cooling climate caused many glaciers to begin advancing, especially after 1970 ('órarinsson, 1974; Björnsson, 1980a; Jóhannesson, 1997; Sigurðsson and Williams, 1998). However, since about 1995, many glaciers have again started to retreat in response to a warmer climate. Glacier fluctuations in Iceland are primarily controlled by variations in summer temperature (Jóhannesson and Sigurðsson, 1998). In Iceland, a change of mass balance generally leads to a reaction of a non-surge-type outlet glacier's terminus within about 5 years (Sigurðsson and Jónsson, 1995).

The ability to monitor changes in a glacier's equilibriumline altitude (ELA) and terminus position, and thus to estimate its mass balance, is a key to long-term monitoring of regional climate. Small glaciers and ice caps are often excellent indicators of regional climate change. With satellite data, decadal-scale changes in the surface expression of glaciers and ice caps, including variations in termini and concomitant changes in area, have been measured. Landsat satellite measurements have been compared with more precise ground measurements (Hall and others, 1992; Williams and others, 1997), and results have shown that Landsat measurements, under many circumstances, can measure glacierterminus changes with an accuracy of $\pm 42 \mathrm{~m}$ (Williams and others, 1997). Synthetic-aperture radar (SAR) data may also be useful for measuring a glacier's terminus position and its firn line and perhaps ELA.

Landsat visible and near-infrared multispectral scanner (MSS) and thematic mapper (TM) data (which also include thermal-infrared data) have been available since 1972 and 1982, respectively. Seasat SAR data were acquired for 100 days in 1978. European Space Agency (ESA) European Remote-sensing Satellite (ERS-1 and/or -2) SAR data have been available since 1991. RADARSAT, a Canadian Space Agency (CSA) SAR, has been available since 1995. With SAR data, even daily changes in the surficial characteristics of ice and snow can be detected through cloud cover (Forster and others, 1997; Smith and others, 1997) subject to sufficient sampling by the sensor. This is in contrast to Landsat data, for which the coverage is dependent on cloud-cover conditions.

Hofsjökull, central Iceland, is the third largest ice cap in Iceland (Fig. 1). Because of its location at a relatively low elevation ( $\sim 1800 \mathrm{~m}$ or below) and latitude $\left(64^{\circ} 50^{\prime} \mathrm{N}\right)$ for such a large ice mass, it is sensitive to changes in atmospheric circulation and oceanic currents in the North Atlantic Ocean. In this paper, we describe the techniques used to measure changes in the surficial characteristics of Hofsjökull (Fig. 2), from analysis of a time series of 57 ERS-1 or -2 SAR scenes from 1994-98, seven ScanSAR scenes from 1997, one Seasat SAR image from 1978, one MSS scene from 1973, and TM scenes from 1986, 1995 and 1997. We also show techniques for locating the firn line and discuss its relationship to the ELA. 


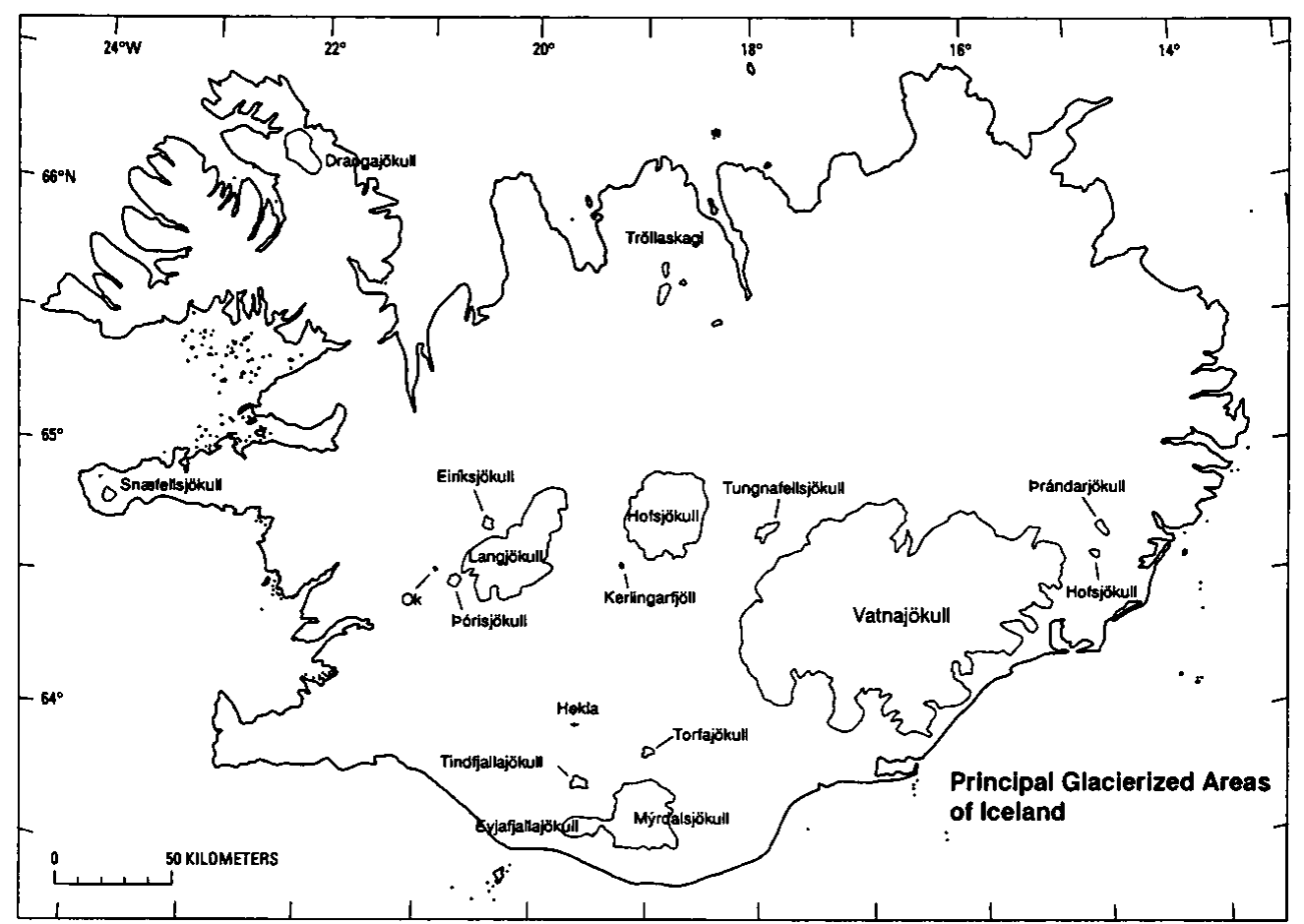

Fig. 1. Index map of the principal glacierized areas of Iceland.

\section{BACKGROUND}

Hofsjökull (Björnsson, 1980b; Williams, 1983, 1987) has an area of $923 \mathrm{~km}^{2}$ (Brown and others, 1999) and a volume of $208 \mathrm{~km}^{3}$ (Björnsson, 1986, 1988). In 1983, the ice-surface elevation and the bedrock below Hofsjökull were measured from barometric altimetry and radio-echo sounding. Ice thickness was calculated at about 42000 echo sounding points, and the ice-surface elevation at about 30000 points (Björnsson, 1988). A large, central volcano with a $250 \mathrm{~km}^{2}$ base at $1000 \mathrm{~m}$ a.s.l. was mapped beneath the ice cap; the sub-glacier volcano rises to $1500-1600 \mathrm{~m}$, around a $600 \mathrm{~m}$

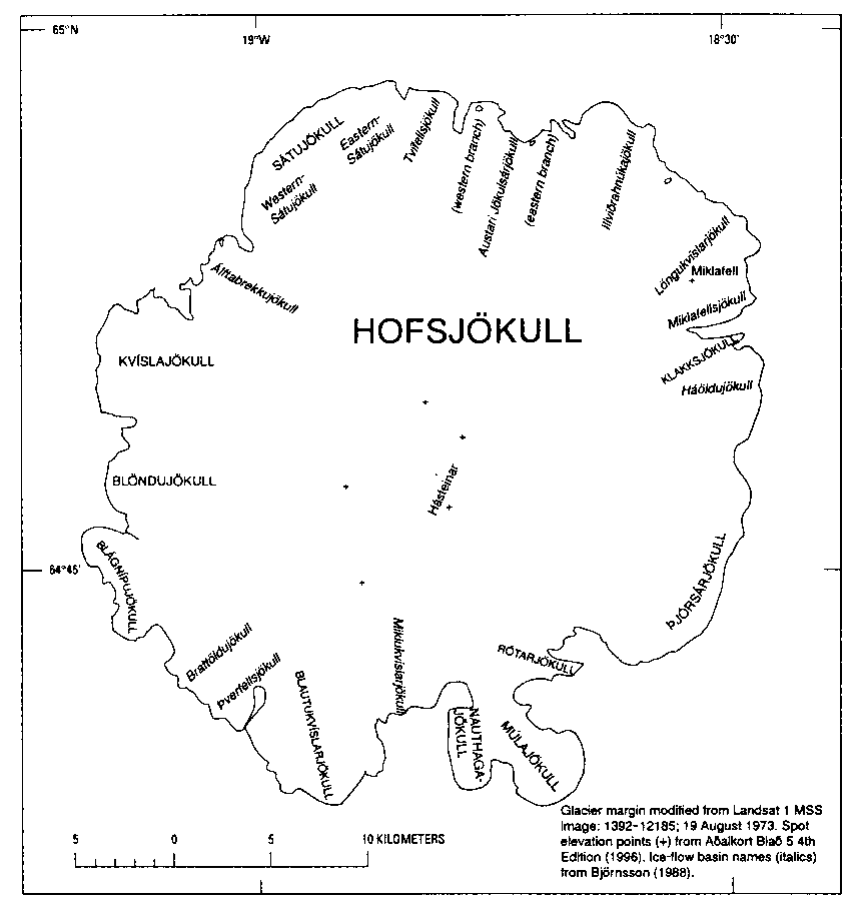

Fig. 2. Hofsjökull, showing its ten named outlet glaciers in capital letters (margin delineated from the 19 August 1973 Landsat 1 MSS image), and ten additional ice-flow basins (in italics) defined by Björnsson (1988). deep caldera. The maximum ice thickness of Hofsjökull is about $750 \mathrm{~m}$ within the caldera, and the average ice thickness of the ice cap is $225 \mathrm{~m}$ (Björnsson, 1986).

ERS C-band SAR data have proven useful for detecting some of the glacier facies and ice-margin moraines and for documenting changes in the location of ice-sheet margins. Landsat MSS and TM data have also proven useful for detecting some of the glacier facies (e.g. Crabtree, 1976; Williams and others, 1979, 1991). However, neither Landsat nor SAR data alone allow an unambiguous measurement of the precise boundaries of all of the glacier facies. This must be done in conjunction with field measurements.

The accumulation area of a glacier may be composed of three facies: the wet-snow facies (where complete soaking of the snow and firn overlying glacier ice occurs in the melt season), the percolation facies (where water percolates into the snow and firn and refreezes as ice pipes, lenses and layers) and the dry-snow facies (where snow and firn never experience surficial or subsurface melt, and no meltwater is produced) (Benson, 1962, 1996). Due to climatic conditions, however, not all glaciers have all three facies.

The ablation area is that part of a glacier located below the equilibrium line; it contains the ice facies. Some of the snow that is raised to the melting point and saturated with water refreezes to form superimposed ice. Superimposed ice straddles the two facies and occupies the superimposed-ice zone (Benson, 1996). The equilibrium line is located just below the superimposed-ice zone, and on temperate glaciers roughly corresponds with the late-summer snowline or the firn line (Paterson, 1994). In winter, the approximate position of the firn line may be apparent in SAR imagery (Lingle and others, 1992, 1997) even when new, dry snow covers both the ablation and accumulation areas.

Ice lenses and layers have been modeled as randomly oriented dielectric cylinders embedded in a dry-snow medium and are responsible for scattering of the microwave signal in the wet-snow and percolation facies of glaciers and ice sheets (Rignot, 1995). SAR backscatter $\left(\sigma^{\circ}\right)$ is lower in the dry-snow facies relative to the percolation facies, because 
the fine grain-sizes of dry snow cause little backscattering of the C-band signal (Rott, 1984; Fahnestock and others, 1993; Rees and others, 1995; Partington, 1998).

Generally, during the melt season, C-band $\sigma^{\circ}$ in the ablation area of a glacier or ice cap is high because the exposed ice surface is rough and scatters the radar signal. The ablation area is rougher during summer than during winter because of stream channeling and differential-ablation effects that occur in summer. In the accumulation area in the melt season, $\sigma^{\circ}$ is low in the wet-snow and percolation facies (e.g. Rott, 1984), when the firn is saturated and volume scattering cannot occur. If a dry-snow facies is present, $\sigma^{\circ}$ is also low due to very low volume scattering.

SAR $\sigma^{\circ}$ boundaries, as seen on ERS SAR images of Greenland, compare well with the boundaries of the glacier facies mapped during Carl Benson's traverses of the Greenland ice sheet in the 1950s (Benson, 1962, 1996; Fahnestock and others, 1993; Partington, 1998). Fahnestock and others (1993) mapped four distinct $\sigma^{\circ}$ zones that were interpreted as corresponding to the dry-snow, percolation, wet-snow and ice facies on the Greenland ice sheet.

Smith and others (1997) utilized 35 ERS-1 SAR images of an ice field in British Columbia, Canada, acquired from 1992 to 1994, to understand the evolution of four dynamic "radar glacier zones", a term coined by Forster and others (1996). The zones represent: (1) cold snow with no liquid water present; (2) an initial "melt front" with an upper boundary near the elevation of the $0^{\circ} \mathrm{C}$ isotherm; (3) rapidly melting first-year snow that is metamorphosed and roughened; and (4) bare glacier ice. Melt onset is signified by a sudden and dramatic decrease in radar $\sigma^{\circ}$ (Smith and others, 1997).

Weather events have been shown by Forster and others (1997) to cause $\sigma^{\circ}$ changes on ice fields on Hielo Patagónico Sur in Chile. For example, an April 1994 rainstorm caused a roughening of the glacier surface which was covered with wet snow, causing an increase in the $\mathrm{X}$-band $(3 \mathrm{~cm}$ wavelength) $\sigma^{\circ}$; the $\sigma^{\circ}$ returned to pre-storm values $3-4$ hours following the rain event. (Earlier, Mätzler and Schanda (1984) observed a similar increase in $\sigma^{\circ}$ from a test site in the Swiss Alps that contained wet snow.) Forster and others (1997) also found, in October 1994 X-band SAR data, that a sudden temperature decrease caused the wet snow to freeze, permitting volume scattering and thus causing an increase in $\sigma^{\circ}$. This has also been observed in the Juneau Icefield using ERS-2 data by Ramage and others (2000).

\section{Satellite sensors and data}

The ERS-1 and -2 satellites, launched in 1991 and 1995, respectively, in near-circular, polar orbits, each carry a SAR operating at C-band (5.3 GHz, $5.6 \mathrm{~cm}$ wavelength), vertical transmit and receive $(\mathrm{VV})$ polarization, with an incidence angle of $19.5-26.5^{\circ}$. The ERS satellites were designed to have a Sun-synchronous orbit and a nominal 35 day repeat cycle. Three-look PRecision Image (PRI) ERS SAR data have $12.5 \mathrm{~m}$ picture-element (pixel) size in ground range and azimuth, a pixel resolution of $33 \mathrm{~m}$ in ground range and $30 \mathrm{~m}$ in azimuth and a $100 \mathrm{~km}$ swath width (Proud and Battrick, 1998).

ERS-1 and -2 data of Hofsjökull were acquired by ESA for most months from January 1994 through March 1998 (Table 1). All of the ERS-1 and -2 SAR scenes were calibrated.

The calibration processor derives the backscatter coeffi- cient $\left(\sigma^{\circ}\right)$ for each pixel of the PRI. The $\sigma^{\circ}$ depends on the physical and electrical properties of the reflecting material, and on the wavelength, polarization and illumination angle of incidence (Raney, 1998). The basic derivation of $\sigma^{\circ}$ from the pixel value, with no topographic correction, is as follows (Laur and others, 1997):

$$
\sigma^{\circ}=\left(D N_{\mathrm{I}, \mathrm{j}}\right)^{2}(1 / K)\left(\sin \alpha / \sin \alpha_{\mathrm{ref}}\right),
$$

where $D N_{\mathrm{I}, \mathrm{j}}$ is the pixel value, $K$ is the calibration constant, $\alpha$ is the local radar incidence angle and $\alpha_{\text {ref }}$ is the reference incidence angle $\left(23^{\circ}\right)$.

Several radiometric corrections are also accounted for in the algorithm. These allow for the correction of on-board instrumentation problems, such as analog-to-digital-converter saturation which can cause errors of $>1 \mathrm{~dB}$ (e.g. Meadows and others, 1998) over large, bright targets such as glaciers in winter, and replica-pulse-power variations which allow for differences between the pulse power used by the satellite and the reference power used by the Processing and Archiving Facility (PAF) processor to generate the image. The algorithm also compensates for inaccurate implementation of the elevation antenna pattern within the PAF processors. The $\sigma^{\circ}$ value calculated is accurate to within $\pm 0.4 \mathrm{~dB}$ except for errors caused by topographic effects (Laur and others, 1997).

RADARSAT-1 carries a C-band $(5.3 \mathrm{GHz}, 5.6 \mathrm{~cm}$ wavelength), horizontal transmit-and-receive $(\mathrm{HH})$ polarization SAR that was launched on 4 November 1995. A variety of resolution, image-swath width and incident-angle parameters is available that may be selected through ground command. Incidence angles of about $20-50^{\circ}$ are available in the standard-imaging modes. Imaging modes for RADARSAT include standard, wide swath, fine resolution, extended and ScanSAR. In each mode, data are collected continuously along a swath parallel to the sub-satellite path. In the ScanSAR wide-swath B mode, as shown in this paper, the pixel size is $100 \mathrm{~m} \times 100 \mathrm{~m}$, the swath width is $510 \mathrm{~km}$ and the incident angles are in the range $20-49^{\circ}$ (Raney, 1998). Seven ScanSAR images, from March to June 1997, were acquired and analyzed.

The Seasat SAR operated between June and October 1978 , at L-band $(1.28 \mathrm{GHz}, 23.5 \mathrm{~cm})$ in a horizontally likepolarized mode with a spatial resolution of about $25 \mathrm{~m}$. The Seasat SAR had a look angle of approximately $20^{\circ}$ and incidence angles that were commonly in the range $0-$ $30^{\circ}$. A Seasat SAR scene from 24 August 1978 was used in this study.

The MSS was first launched in July 1972 on board the Landsat 1 satellite, providing images of the same point on the Earth once every 18 days, cloud cover permitting, at a pixel resolution of approximately $80 \mathrm{~m}$, in four spectral bands in the visible and near-infrared parts of the electromagnetic spectrum. The TM sensor was first carried on the Landsat 3 satellite in 1982 with a 16 day repeat cycle. It provides $30 \mathrm{~m}$ pixel resolution images of the Earth's surface in seven spectral bands, ranging from the visible to the thermal-infrared parts of the spectrum. Landsat data of the following dates were analyzed for this study: MSS data from 19 August 1973 (Fig. 3) and TM data from 16 September 1986, 24 August 1995 and 13 August 1997.

\section{Meteorological data}

The following meteorological data were acquired from the Icelandic Meteorological Service in Reykjavík, for the 
Table 1. SAR data of Hofsjökull, acquired from ESA (ERS-1 or -2) and CSA (RADARSAT) (R)

\begin{tabular}{|c|c|c|c|c|c|c|c|c|c|c|}
\hline \multirow{2}{*}{ Month } & \multicolumn{2}{|c|}{1994} & \multicolumn{2}{|c|}{1995} & \multicolumn{2}{|c|}{1996} & \multicolumn{2}{|c|}{1997} & \multicolumn{2}{|c|}{1998} \\
\hline & Tape date & ERS & Tape date & ERS & Tape date & ERS & Tape date & $E R S / R$ & Tape date & ERS \\
\hline Jan. & 14 Jan. & 1 & 18 Jan. & 1 & $\begin{array}{l}\text { 2 Jan. } \\
\text { 3 Jan. }\end{array}$ & $\begin{array}{l}1 \\
2\end{array}$ & 22 Jan. & 2 & $\begin{array}{l}6 \text { Jan. } \\
7 \text { Jan. }\end{array}$ & $\begin{array}{l}2 \\
2\end{array}$ \\
\hline Feb. & $\begin{array}{l}16 \text { Feb. } \\
19 \text { Feb. }\end{array}$ & $\begin{array}{l}1 \\
1\end{array}$ & 24 Feb. & 1 & $\begin{array}{l}6 \text { Feb. } \\
7 \text { Feb. }\end{array}$ & $\begin{array}{l}1 \\
2\end{array}$ & 26 Feb. & 2 & 11 Feb. & 2 \\
\hline Mar. & 15 Mar. & 1 & 28 Mar. & 1 & 12 Mar. & 1 & $\begin{array}{l}14 \text { Mar. } \\
28 \text { Mar. }\end{array}$ & $\begin{array}{l}2 \\
\mathrm{R}\end{array}$ & 17 Mar. & 2 \\
\hline Apr. & 27 Apr. & 1 & 13 Apr. & 1 & 15 Apr. & 1 & $\begin{array}{l}1 \mathrm{Apr} . \\
3 \mathrm{Apr} . \\
4 \mathrm{Apr} . \\
11 \mathrm{Apr} . \\
18 \mathrm{Apr} .\end{array}$ & $\begin{array}{l}\mathrm{R} \\
\mathrm{R} \\
\mathrm{R} \\
\mathrm{R} \\
2\end{array}$ & $\mathrm{n} / \mathrm{a}$ & \\
\hline May & 18 May & 1 & 2 May & 1 & 3 May & 2 & 7 May & 2 & $\mathrm{n} / \mathrm{a}$ & \\
\hline June & 24 June & 1 & 6 June & 1 & 7 June & 2 & $\begin{array}{l}10 \text { June } \\
11 \text { June } \\
12 \text { June }\end{array}$ & $\begin{array}{l}\mathrm{R} \\
2 \\
\mathrm{R}\end{array}$ & $\mathrm{n} / \mathrm{a}$ & \\
\hline July & $\begin{array}{l}30 \text { July } \\
31 \text { July }\end{array}$ & $\begin{array}{l}1 \\
1\end{array}$ & 11 July & 1 & 31 July & 2 & 16 July & 2 & $\mathrm{n} / \mathrm{a}$ & \\
\hline Aug & 20 Aug & 1 & $\begin{array}{l}15 \mathrm{Aug} \\
16 \mathrm{Aug}\end{array}$ & $\begin{array}{l}1 \\
2\end{array}$ & $16 \mathrm{Aug}$ & 2 & 1 Aug & 2 & $\mathrm{n} / \mathrm{a}$ & \\
\hline Sept. & 26 Sept. & 1 & 20 Sept. & 2 & 4 Sept. & 2 & 5 Sept. & 2 & $\mathrm{n} / \mathrm{a}$ & \\
\hline Oct. & $\mathrm{n} / \mathrm{a}$ & & $\begin{array}{l}8 \text { Oct. } \\
25 \text { Oct. }\end{array}$ & $\begin{array}{l}2 \\
2\end{array}$ & 9 Oct. & 2 & 10 Oct. & 2 & $\mathrm{n} / \mathrm{a}$ & \\
\hline Nov. & 22 Nov. & 1 & 29 Nov. & 2 & 13 Nov. & 2 & 29 Nov. & 2 & $\mathrm{n} / \mathrm{a}$ & \\
\hline Dec. & 29 Dec. & 1 & 15 Dec. & 2 & 18 Dec. & 2 & 3 Dec. & 2 & $\mathrm{n} / \mathrm{a}$ & \\
\hline
\end{tabular}

period January 1994-September 1997 for the meteorological station in the central highlands at Hveravellir: daily average air temperature, precipitation, cloud cover and hours of sunshine. Because Hveravellir ( $64^{\circ} 52^{\prime} \mathrm{N}, 19^{\circ} 34^{\prime} \mathrm{W}$; $641 \mathrm{~m}$ a.s.l.) is situated in a "saddle" between the Hofsjökull and Langjökull ice caps and is in a precipitation shadow, the amount of pre-

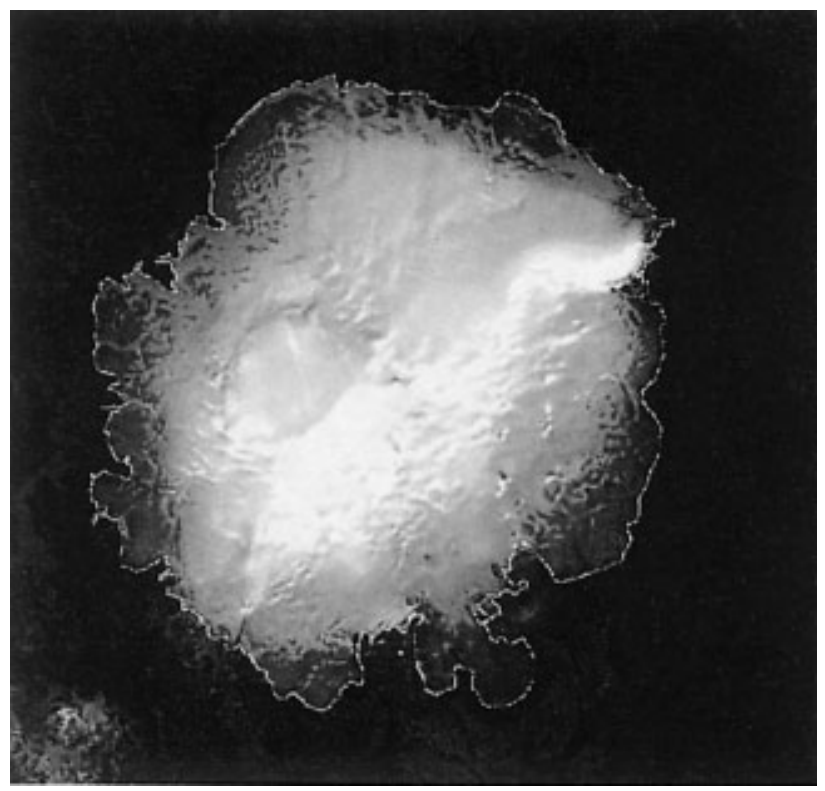

Fig. 3. 19 August 1973 Landsat 1 MSS image (i.d. No. 139212185) (path/row, 237/14) band $4(0.8-1.1 \mu \mathrm{m})$ of Hofsjökull. Note the caldera rim of the sub-glacier central volcano in the west-central part of the ice cap. cipitation there is not representative of the amount of precipitation on Hofsjökull, which is at a higher elevation. For example, the annual average precipitation (1994-98) at Hveravellir is $664 \mathrm{~mm}$. The annual average precipitation at the terminus of Múlajökull, a surge-type piedmont outlet glacier of Hofsjökull (Figs 2 and 4), is estimated to be about $1200 \mathrm{~mm}$ (Sigfúsdóttir, 1964) and the mean annual precipitation at the summit of Hofsjökull has been about $4000 \mathrm{~mm}$ w.e. since 1988 (Sigurðsson and Jónsson, 1995). This demonstrates the large orographic effect on precipitation on Hofsjökull.

\section{RESULTS AND DISGUSSION}

\section{Methodology}

A digital elevation model (DEM) of Hofsjökull was constructed using SAR interferometry (InSAR) and the GTOPO 30 topographic map of Iceland (Fig. 5). In addition, geodetic ground-control points were determined from conventional topographic maps (1:50000 scale Series C761 from the National Land Survey of Iceland) (Barton and others, 2000). The accuracy of the InSAR part of the DEM was assessed using a University of Iceland Science Institute (UISI) topographic map of Hofsjökull (Björnsson, 1986, 1988) that was digitized to facilitate comparison with the DEM (Fig. 6). Construction of the InSAR DEM allowed us to facilitate plotting the backscatter data from the ERS-1 and -2 scenes, though the InSAR DEM does not otherwise necessarily represent an advantage over the University of Iceland DEM. 


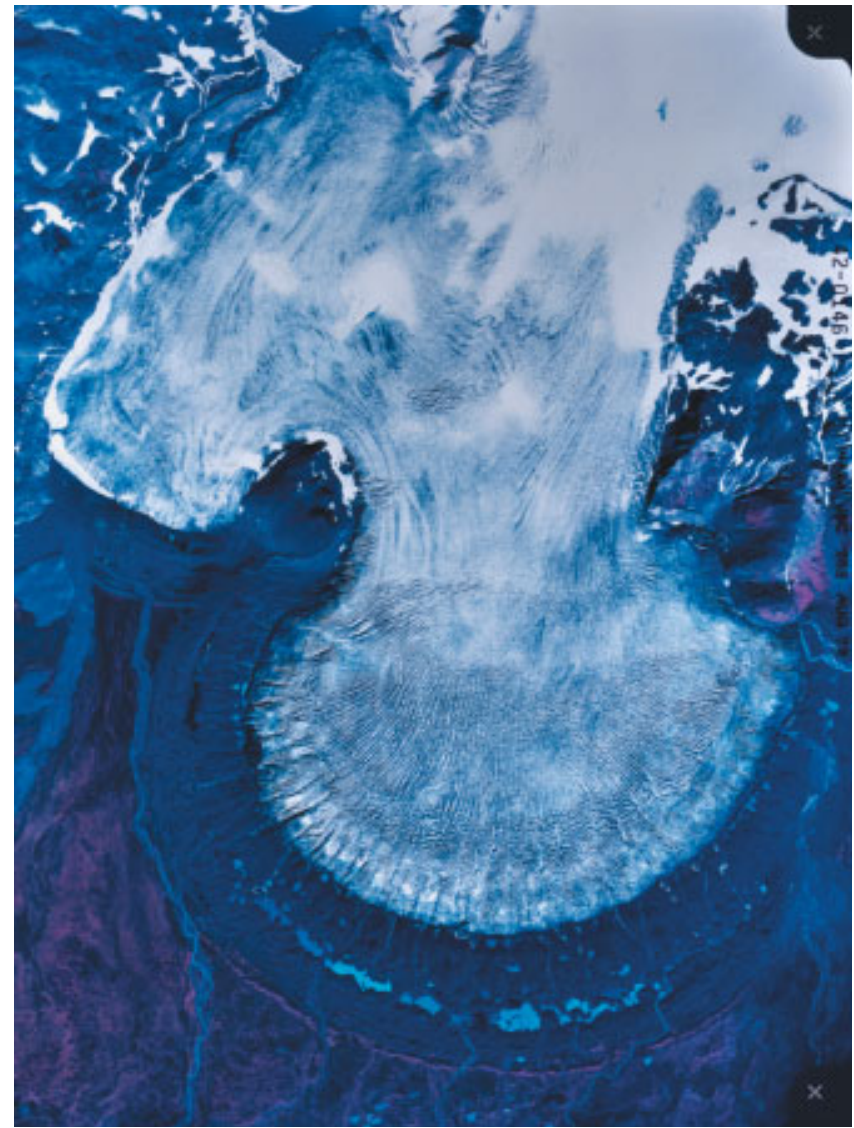

Fig. 4. Vertical color-infrared aerial photograph of Múlajökull, a surge-type piedmont outlet glacier of Hofsjökull, 1 year after a $370 \mathrm{~m}$ surge. Photo No. 146, roll 42, from NASA Mission 253 (test site 714) acquired on 19 August 1973, the same date as the Landsat $1 \mathrm{image}$ ( see Fig. 3), from an altitude of $3300 \mathrm{~m}$ (approximate original photo scale 1:20 000).

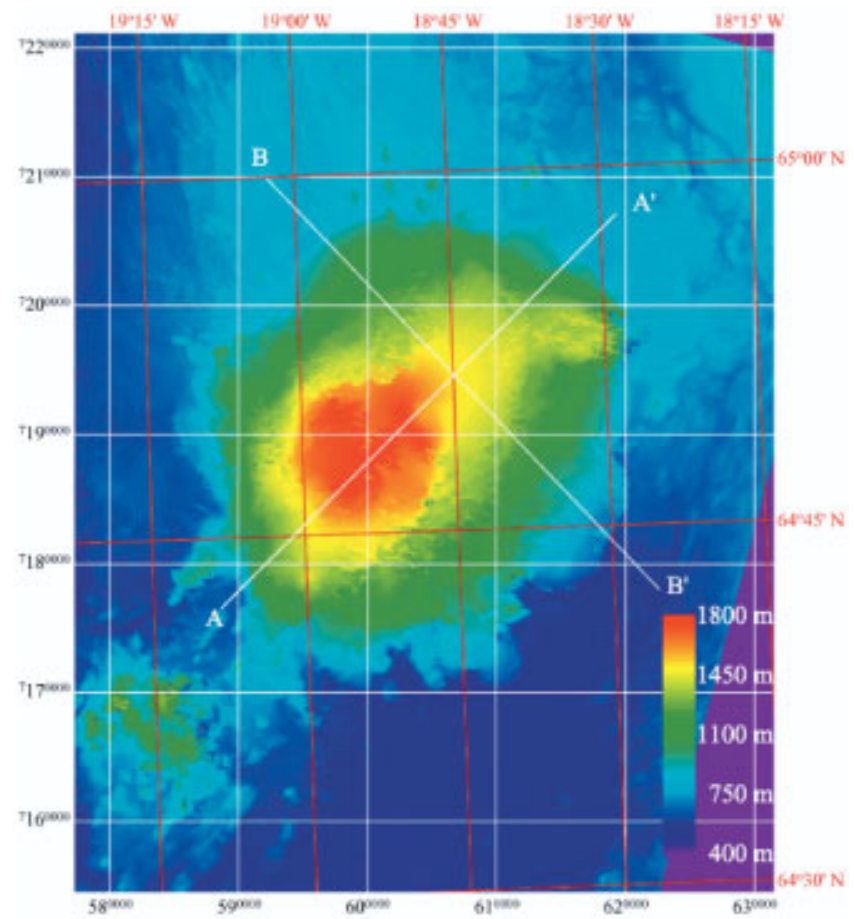

Fig. 5. DEM of Hofsjökull calculated using the 6-7 February ERS-1/-2 pair and GTOPO30. The DEM is presented in the UTM zone 27 coordinate space, with a horizontal datum ". The maximum and minimum elevation is 1840 and $559 \mathrm{~m}$, respectively. The location of the transect across Hofsjökull is shown in black. The transect, used to develop backscatter plots in Figures 7-10, is shown.
Aerial photogrammetry, which requires the visual determination of elevation using contrast between overlapping vertical aerial photographs or satellite images, is not accurate over snow-covered glaciers. Such areas appear as monotonous areas of high reflectivity with virtually no contrast. Determination of elevation contours on stereoscopic images is therefore impossible. Thus the use of GTOPO30, alone, for determination of the DEM is not ideal because aerial photographs were used, in part, to derive GTOPO30 (e.g. derived from U.S. National Imagery and Mapping Agency (NIMA) Series 1501 maps (1:250000 scale of Iceland) which, in turn, was derived from geodetically deficient accelerator mass spectrometry (AMS) Series C762 maps (1:50000 scale of Iceland)).

The principle behind SAR interferometry is that there is a shift in phase between two coherent radar echos acquired from slightly different positions of observation of the same target. The displacements result from the combined effects of the slight offset in position of the two SAR antennas between different orbits, the topographic height of the scattering centers and any motion of the scatterers (Goldstein and others, 1993; Zebker and others, 1994; Joughin and others, 1996, 1998; Rignot and others, 1996; Mattar and others, 1998).

To derive a DEM using SAR interferometry, a number of processing steps are required. First, the two complex SAR images must be co-registered precisely to optimize their coherence (signal-to-noise ratio). Relative phase is then calculated from the co-registered image pair and this is then converted from its "modulo $2 \pi$ " form to absolute values in a process called phase unwrapping. For this work, the phase-unwrapping scheme of Goldstein and others (1988) was used. The satellite baseline, derived from the two satellite orbits and the ground-control points, is used to convert unwrapped phase into units of surface elevation.

The InSAR DEM of Hofsjökull (Fig. 5) was calculated from a 6-7 February 1996 ERS-1/-2 pair, which has a perpendicular baseline of $208.8 \mathrm{~m}$ (Barton and others, 2000). In order to remove fringes due to ice motion, another interferogram, calculated from a 2-3 January 1996 pair, from a perpendicular baseline of $88.9 \mathrm{~m}$, was combined with the GTOPO30 topographic map to produce a motion map. This motion map was then subtracted from the February interferogram to produce a topography-only interferogram. This was then unwrapped, and referenced to 20 groundcontrol points on the land surrounding the glacier. A DEM was then produced using a refined baseline estimate. Values from GTOPO30 were used to fill areas where a lack of coherence produced decorrelation which impeded the unwrapping process. This was necessary in order to produce a complete DEM for development of the backscatter plots.

The InSAR DEM of Hofsjökull is presented in Universal Transverse Mercator (UTM) zone 27 coordinate space (zone 27 runs from $18^{\circ}$ to $\left.24^{\circ} \mathrm{W}\right)$. The elevations shown are relative to sea level. Elevations are relative to the World Geodetic System (WGS84) ellipsoid. All of the processing done in this

\footnotetext{
* Local horizontal datum used by the National Land Survey of Iceland and NIMA for the series C761 1:50,000scale maps of Iceland; the map series uses mean sea level as the vertical datum, a Transverse Mercator projection, the international ellipsoid, and a $1000 \mathrm{~m}$ Universal Transverse Mercator zone grid.
} 

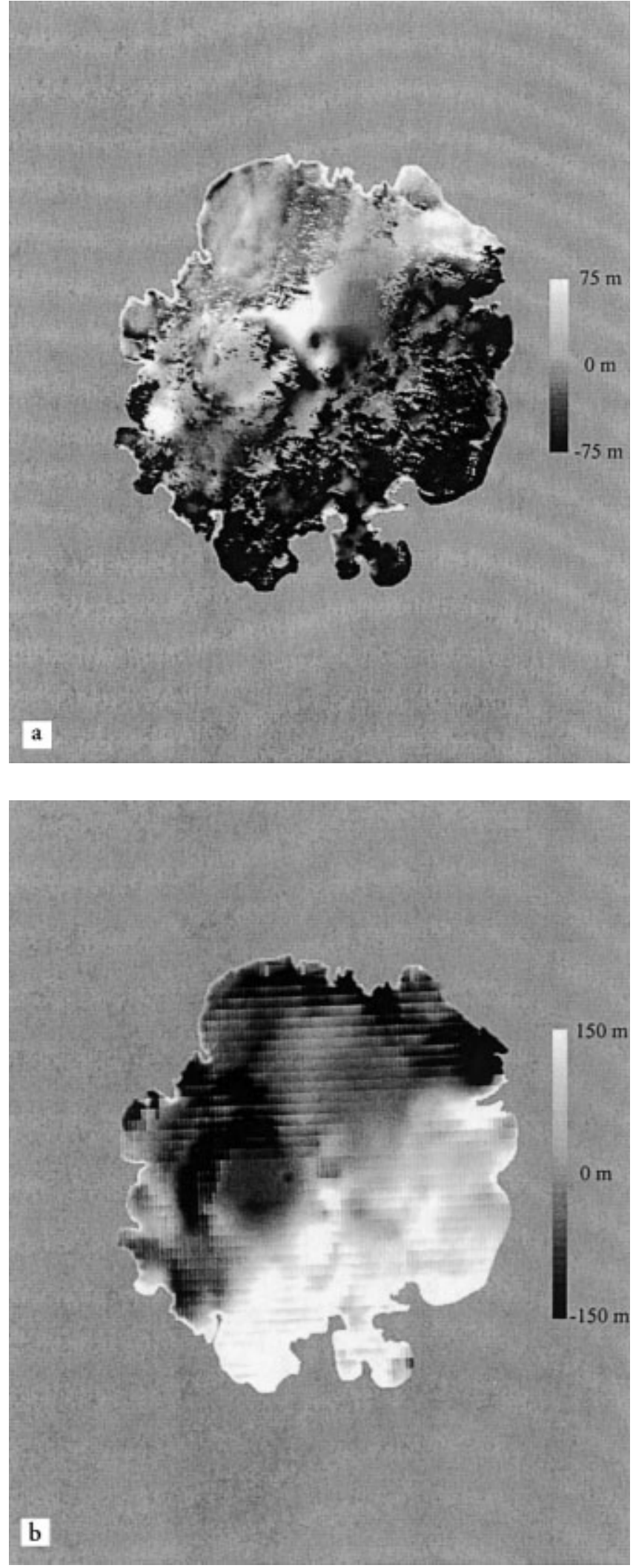

DEM generation utilized the Gamma Remote Sensing (Gamma) Modular SAR Processor (MSP) and the Gamma Interferometric SAR Processor (ISP). The processing and geocoding was done using the Gamma ISP, and subsequent visualization was done using the Research Systems Inc. (RSI) Environment for Visualizing Images (ENVI) computer software.

The accuracy of the InSAR DEM relative to the digitized version of the UISI topographic map was evaluated. Figure 6a shows elevations from the InSAR DEM minus elevations from the digitized UISI topographic map. The black represents areas where the InSAR elevations are

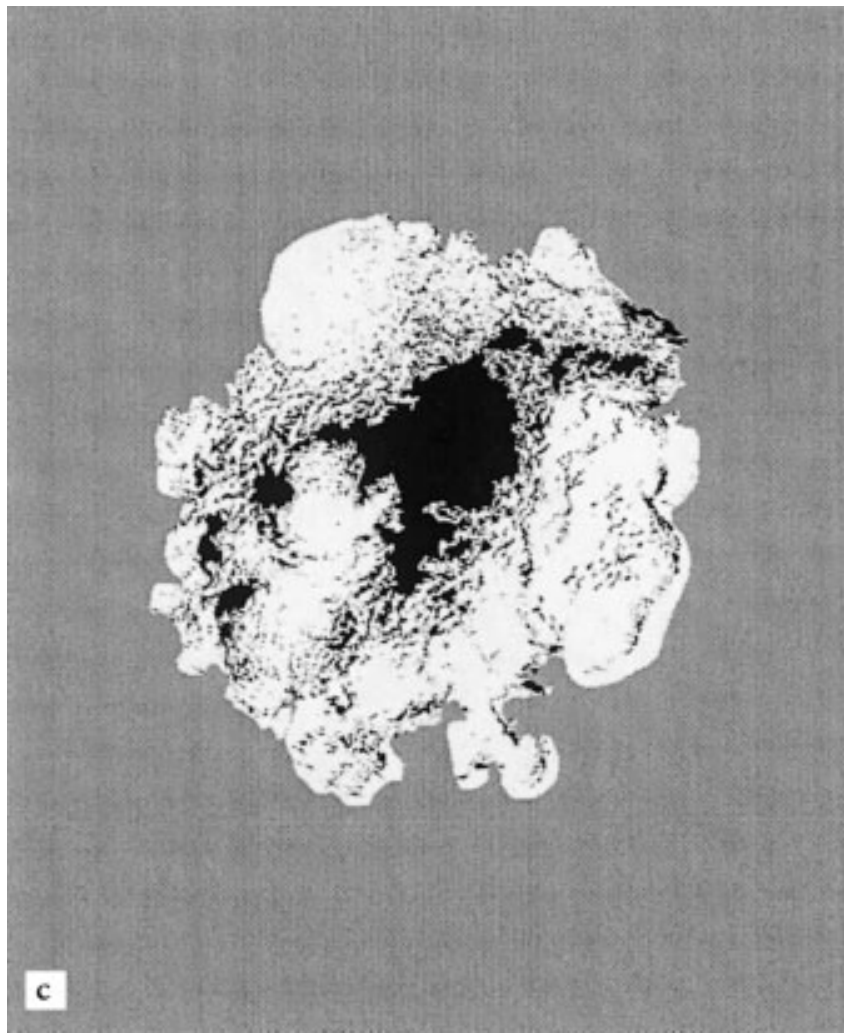

Fig. 6. (a) Comparison of the InSAR DEM and the UISI $D E M$. This difference map shows elevations from the InSAR DEM minus elevations from the digitized UISI topographic map of Hofsjökull. (b) Comparison of the UISI DEM and GTOPO30. This difference map shows elevations from GTOPO30 minus elevations from the digitized UISI topographic map. (c) Areas of Hofsjökull where decorrelation prevented interferometrically derived elevations from being produced are shown in black; in these areas, elevations from GTOPO 30 were substituted to develop the InSAR DEM shown in Figure 5.

lower than UISI elevations. (Areas of radar layover and areas where slight misregistration occurred between images are not shown.) Figure 6b shows elevations from GTOPO30 minus elevations from the digitized UISI DEM. The black represents areas where the GTOPO30 elevations are lower than UISI elevations.

The errors present in the InSAR DEM (including the ramp), shown in Figure 6a, are largely due to the dependence of the InSAR elevation calculation on the GTOPO30 elevations. Although the use of the pair of scenes from January minimizes the effect of low-magnitude errors in the DEM because of the small baseline, the large-scale ramp 
seen in Figure 6b does have a significant effect on the motion calculation. In this case, the roughly $150 \mathrm{~m}$ errors in the GTOPO30 DEM will result in errors of $2 \pi$ in the motion interferogram. Since the motion information is then used with the longer baseline data from February, the sensitivity to the motion information is reduced by about a factor of two; however, some of the error is passed on to the final DEM. The ultimate result is a reduction in the magnitude of the error and an inversion of the sign.

Areas of Hofsjökull where decorrelation prevented interferometrically derived elevations from being produced are shown in Figure 6c in black; in these areas, elevations from GTOPO30 were substituted to develop the InSAR DEM shown in Figure 5. Because of these errors, it would be beneficial to use the University of Iceland map for the motion analysis, instead of GTOPO30. However, because there is incomplete information available about the precise projection parameters used to create the University of Iceland map, it is impossible to co-register the data with sufficient precision for processing. An alternative method would be the utilization of additional ERS data for use in three- or four-pass interferometry, but insufficient data correlation over the 35 day repeat interval during the tandem mission, and even, in most cases, between tandem pairs, makes this method impractical.

\section{SAR backscatter plots}

Backscatter, along a generally southwest-northeast transect (A- $\mathrm{A}^{\prime}$ in Fig. 5) is plotted along with elevation and air temperature. No additional multilooking beyond the three nominal looks of the ERS PRI images was done during the calculation of the backscatter for these plots. A lapse rate of $0.67^{\circ}(100 \mathrm{~m})^{-1}$ was used to calculate air temperature at different elevations on the ice cap using air temperatures from Hveravellir. Topographic information was derived from the InSAR DEM. These plots are shown in Figures 7-10. All plots were calculated from transect $\mathrm{A}-\mathrm{A}^{\prime}$, except the plot shown in Figure $7 \mathrm{~b}$ which was taken from transect $\mathrm{B}-\mathrm{B}^{\prime}$ (also shown in Fig. 5).

Seasonal $\sigma^{\circ}$ patterns are generally consistent in the four years analyzed: 1994, 1995, 1996 and 1997. There are four predominant $\sigma^{\circ}$ patterns or regimes. The winter regime begins by November of each year. The spring transitional regime is March-June. The summer regime occurs roughly in July and August. The fall transitional regime occurs in September and October. Variations in weather conditions cause differences in the timing of the start and duration of the seasonal $\sigma^{\circ}$ regimes between years.

\section{Winter regime}

During the winter regime (Fig. 7a), $\sigma^{\circ}$ is generally the least variable. $\sigma^{\circ}$ in the higher-elevation parts of the ice cap is high and ranges from about -5 to $5 \mathrm{~dB}$. The high $\sigma^{\circ}$ is caused by the presence of ice lenses and layers in the snow in the accumulation area, which is well below freezing during most of the winter. (As with all of Iceland's ice caps, there is no dry-snow facies on Hofsjökull.) Large spikes (up to $13 \mathrm{~dB}$ in winter) may be observed in the $\sigma^{\circ}$ data (not shown) around the caldera. These are caused by the presence of nunataks (rock outcrops) on the rim of the subglacier caldera, which reflects the radar signal strongly.

At the margins of the ice cap (in the ablation area), $\sigma^{\circ}$ is more variable and much lower during winter than it is in the accumulation area. The dry, winter snow cover over bare ice in the ablation area does not produce much volume scattering, probably because there are few ice lenses or layers embedded in the dry snow to produce significant backscatter.

A sharp drop in $\sigma^{\circ}$ is seen in most of the winter $\sigma^{\circ}$ regime scenes. This may be seen most clearly on the western side of the transect $\mathrm{B}-\mathrm{B}^{\prime}$ at about $10000 \mathrm{~m}$ in Figure $7 \mathrm{~b}$. This $\sigma^{\circ}$ drop corresponds to the location of the firn line, as discussed in the next section. The winter is a very good time to identify the $\sigma^{\circ}$ boundary representing the late-summer snowline, because new snow is nearly transparent to the microwave signal. However, the firn in the accumulation area, with its ice lenses and layers, scatters the radar signal (Lingle and others, 1992, 1997). If superimposed ice is present, it is not likely to be detected by the SAR because when frozen it is not distinguishable from the bare ice of the ice facies (Bindschadler and Vornberger, 1992). The presumed firn line may be seen at nearly the same place in both the latesummer SAR and Landsat imagery as discussed later.

\section{Spring regime}

The spring transitional regime is characterized by sharply dropping $\sigma^{\circ}$ in response to wetting of the glacier surface as the air temperature rises to near and above $0^{\circ} \mathrm{C}$, first at the lower elevations and then at the higher elevations (Fig. 8). Warmer air temperatures in 1995 (relative to 1994, 1996 and 1997) caused melting in the ablation area and thus lowered $\sigma^{\circ}$, while the May plots for 1994, 1996 and 1997 still display $\sigma^{\circ}$ patterns similar to those found in the winter regime. On 2 May 1995, the $\sigma^{\circ}$ is high on parts of the ice cap where the surface air temperature is still below about $-5^{\circ} \mathrm{C}$.

\section{Summer regime}

The summer $\sigma^{\circ}$ regime consists of very low values $(-25 \mathrm{~dB}$ or lower) over nearly all parts of the ice cap. ( $\sigma^{\circ}$ spikes, caused by the nunataks (not shown), are present in summer, as they are in the winter imagery.) However, $\sigma^{\circ}$ is generally higher in the ablation area (ice facies) than in the accumulation area, probably due to scattering from the rough (up to $1 \mathrm{~m}$ amplitude), snow-free ice surface.

\section{Fall regime}

When the air temperature at the ice-cap summit was just below freezing, on 20 September 1995, 4 September 1996 or 5 September 1997 (Fig. 10), $\sigma^{\circ}$ is still variable, but the very cold air temperatures on 26 September $1994\left(<-10^{\circ} \mathrm{C}\right.$ at the summit area) caused the surficial snow and firn to refreeze, resulting in higher $\sigma^{\circ}$ than was observed in the scenes from other years. The lower air temperatures freeze surface water, firn and wet snow, enabling penetration of the C-band signal and thus volume scattering, which results in a $\sigma^{\circ}$ increase. According to our observations, the effects of melt on the SAR $\sigma^{\circ}$ signal are noticeable when the air temperature rises to between $-5^{\circ}$ and $0^{\circ} \mathrm{C}$.

\section{Determination of areal extent of Hofsjökull using Landsat and ERS-2 data}

Changes in the extent of the ice margin of Hofsjökull may be studied using both Landsat and SAR data, but Landsat data often allow a better measurement of glacier area. Using SAR, there is often a poor $\sigma^{\circ}$ contrast between an outlet or valley glacier terminus or an ice-sheet margin and the surrounding moraine (see, e.g., the eastern part of Hofsjökull in Fig. 11 on the ERS-2 SAR scene acquired on 5 September 

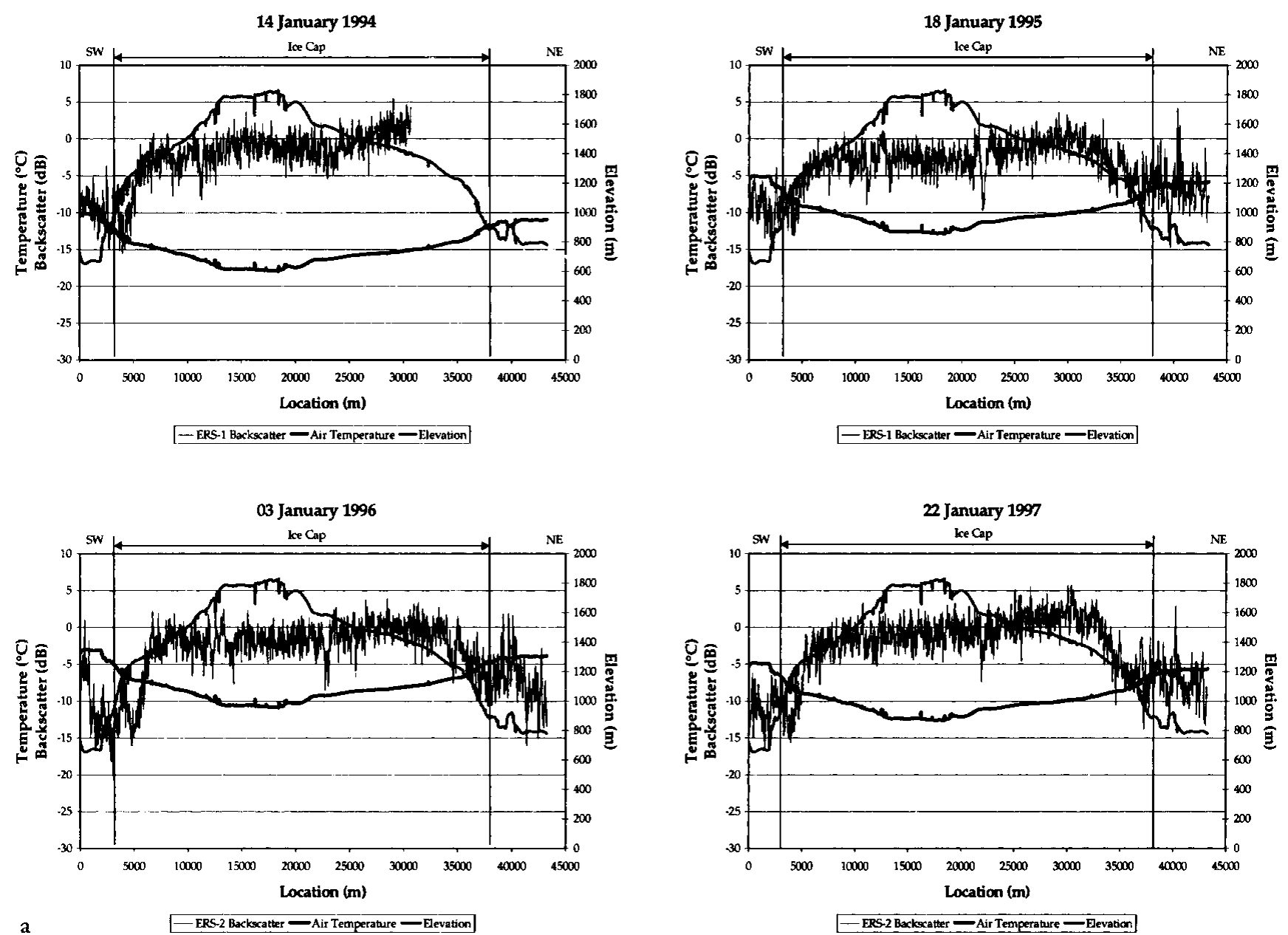

a

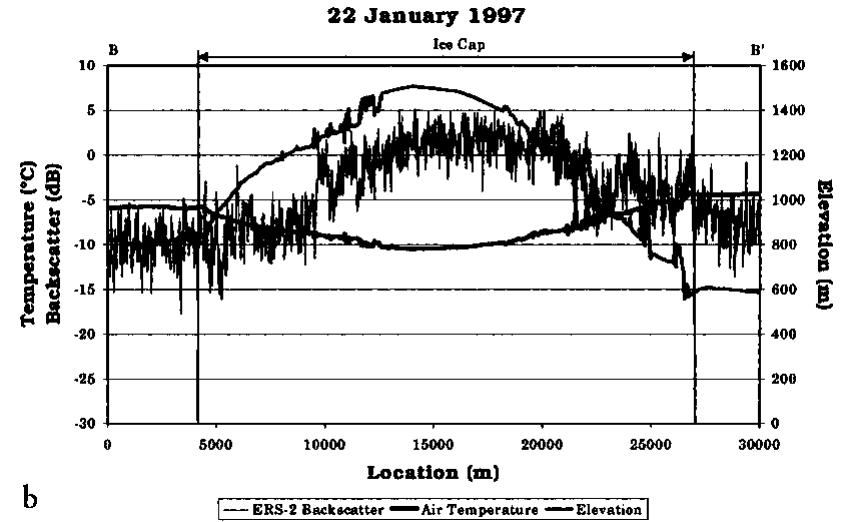

1997). Radar layover may further complicate the accurate measurement of the ice-cap margin as seen on the northeastern part on both of the SAR scenes of Hofsjökull in Figure 11, where a steep mountain slope strongly resembles the margin of the ice cap.

A poor contrast between a glacier and the surrounding moraine may also be found on Landsat data of receding glaciers, because the debris-covered ice surface may be indistinguishable from the surrounding moraine (Hall and others, 1995). However, MSS imagery of Hofsjökull from 19 August 1973 (scene i.d. No. 1392-12185) (Fig. 3) and TM imagery from 16 September 1986 (scene i.d. No. 52180150086259 (not shown)), 24 August 1995 (5218015009523610) (not shown), and 13 August 1997 (52180150097225) (Fig. 11) generally show excellent contrast with the surrounding area, and only a few changes in the intervening years. MSS and TM data are often excellent for use in measuring glacier-terminus position (Crabtree, 1976; Williams and others, 1979; Hall and others,

\begin{abstract}
Fig. 7. (a) January three-look $\sigma^{\circ}$ plotted along a transect $\left(A-A^{\prime}\right)$ (see Fig. 5) of Hofsjökull, with elevation derived from the DEM and air temperature calculated from values reported at Hveravellir. Horizontal arrows at the top of each plot show the ice cap; the vertical lines show the ice-cap margins. On 14 January 1994, the $\sigma^{\circ}$ plot is not complete due to a problem with the SAR data. (b) January three-look $\sigma^{\circ}$ plotted along a transect ( $\left.B-B^{\prime}\right)$ ( see Fig. 5) of Hofsjökull, with elevation derived from the DEM and air temperature calculated from values reported at Hveravellir. Horizontal arrows at the top of the plot show the ice cap; the vertical lines show the ice-cap margins.
\end{abstract}

1992). This is especially true in the case of advancing glaciers which generally have very "clean" termini.

While most of the margin of the ice cap remained stable between 1973 and 1997, there was an advance of Pjórsárjökull (see Fig. 2 for location) of approximately $532 \mathrm{~m}$ as measured using Landsat data from 1973 and 1997. In 1991/92, a surge caused the southernmost third to advance $\sim 300 \mathrm{~m}$, and during a 1994/95 surge the middle third also advanced $\sim 300 \mathrm{~m}$. This advance, relative to the MSS-derived margin, may be seen in Figure 11 on the TM image acquired on 13 August 1997; the outline in yellow represents the position of the margin of Hofsjökull as derived from the 19 August 1973 MSS image. The advance of Djórsárjökull may also be seen in the SAR images in Figure 11 where we measured a $630 \mathrm{~m}$ advance from 1973 (using MSS data) to 1997 (using SAR data). Ground measurements are not available to confirm the actual advance of Pjórsárjökull, and the Landsat and SAR measurements disagree. 


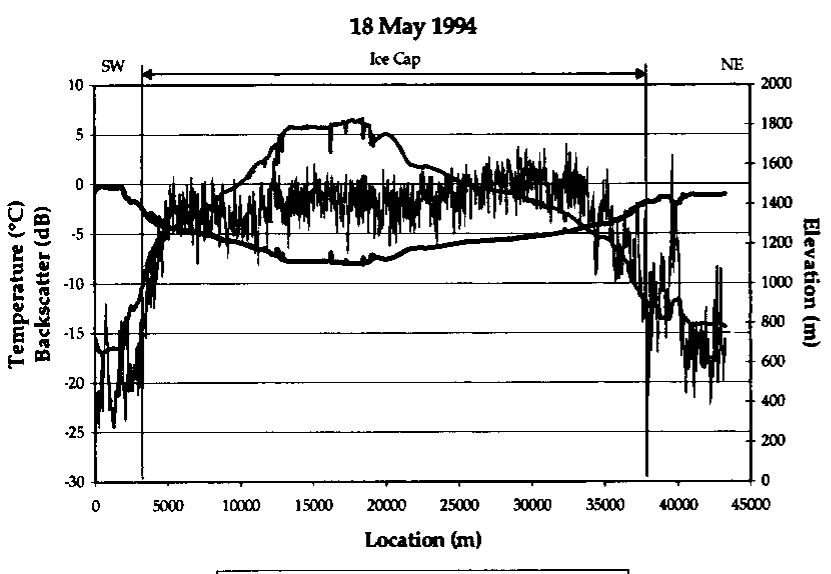

E-ERS-1 Backscatter - Air Temperature - Elevation

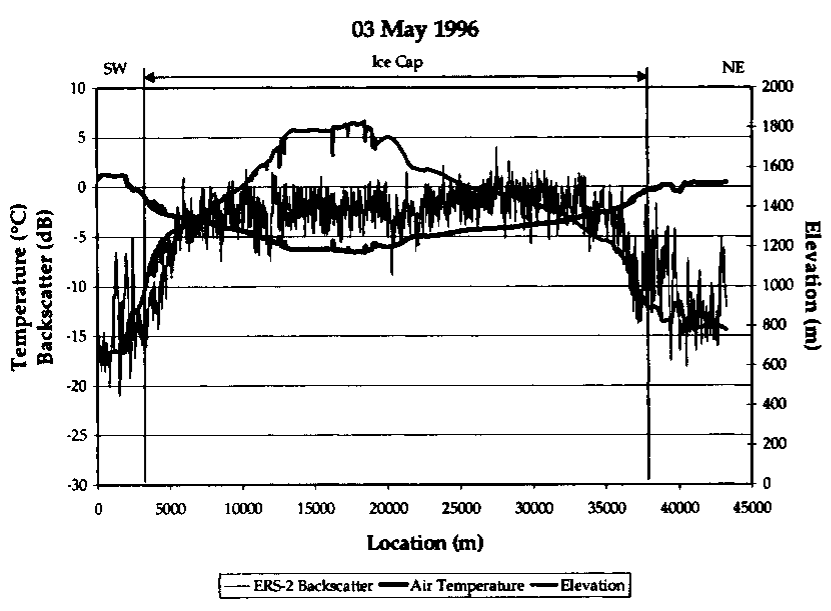

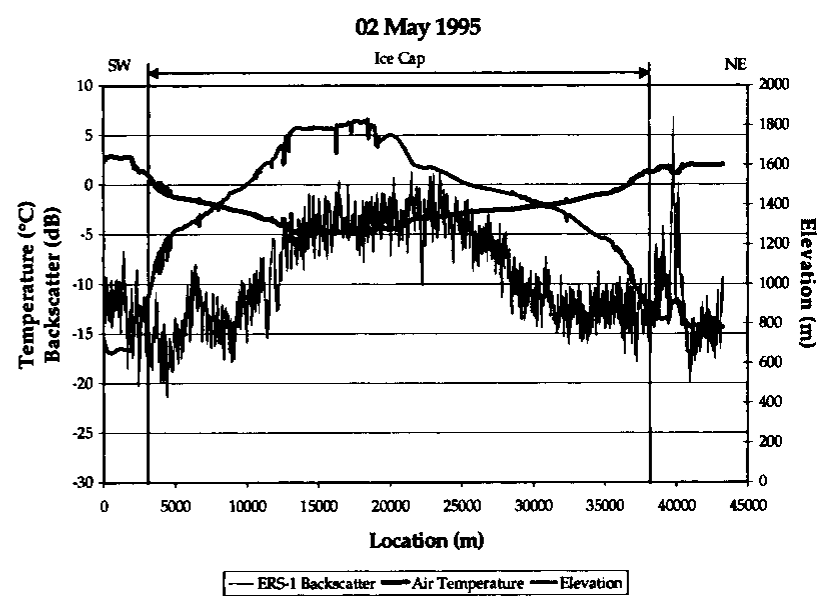

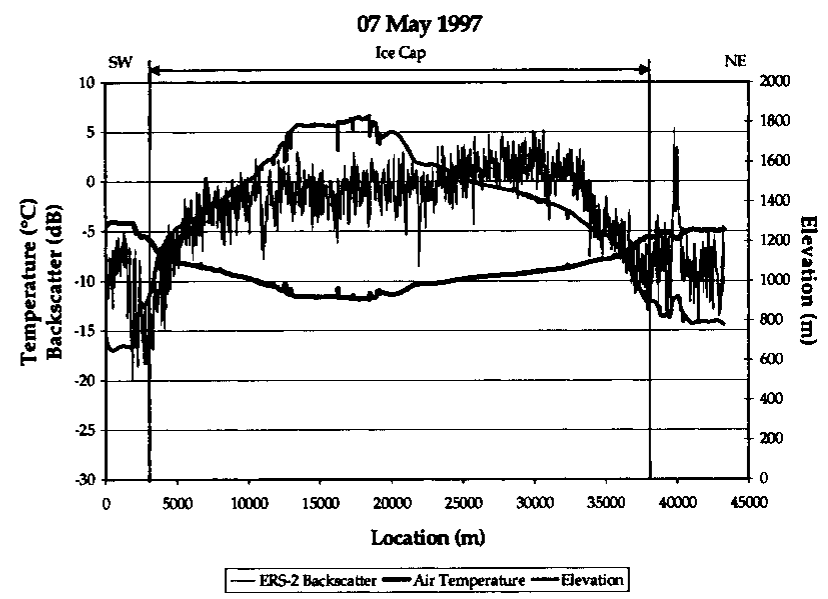

Fig. 8. May three-look $\sigma^{\circ}$ plotted along a transect $\left(A-A^{\prime}\right)$ (see Fig. 5) of Hofsjökull, with elevation derived from the DEM and air temperature calculated from values reported at Hveravellir. Horizontal arrows at the top of each plot show the ice cap; the vertical lines show the ice-cap margins.

Topographic controls on the firn line on Hofsjökull as seen on Landsat and ERS-2 data

Comparison of the false-color TM band $5(1.55-1.75 \mu \mathrm{m}), 4$ $(0.76-0.9 \mu \mathrm{m}) 2(0.52-0.60 \mu \mathrm{m})$ composite image, acquired on 13 August 1997, with the ERS-2 SAR image acquired on 5 September 1997 (Fig. 11) reveals that the high-reflectance parts of the ice cap (seen in the TM image in light blue) correspond very closely with the areas of low SAR backscatter or the areas that we have interpreted to be saturated snow in the accumulation area. The ice facies in the ablation area is largely free from overlying snow but is wet; it gives higher SAR returns than does the wet snow in the accumulation area, because the ice facies is composed of rough ice which scatters a larger proportion of the microwave energy back toward the sensor. The wet-snow facies is composed of smooth, wet snow that absorbs the microwave signal. The bare ice in the ice facies has a lower visible and near-infrared reflectance (as seen on the TM scene) than does the wet snow and firn found in the higher elevations. Also in Figure 11, the ERS-2 SAR scene acquired on 7 January 1998 reveals that the approximate position of the firn line is apparent through the winter snow cover. This same pattern was seen in late-summer $1995 \mathrm{TM}$ and SAR imagery and in January 1996 SAR imagery (not shown).

As determined from our DEM of Hofsjökull, as registered to the winter SAR scenes, the firn line occurs approximately $1000 \mathrm{~m}$ a.s.l. in all of the January SAR scenes from 1994-98, in the east-central part of the ice cap, where the average annual air temperature $(1994-98)$ is $-0.7^{\circ} \mathrm{C}$ at Hveravellir, or approximately $-3^{\circ} \mathrm{C}$ at $1000 \mathrm{~m}$ a.s.l. In the western part of the ice cap, the firn line occurs at $\sim 1300 \mathrm{~m}$ a.s.l., where the average annual air temperature is approximately $-5^{\circ} \mathrm{C}$. The TM and SAR sensors provide independent confirmation concerning the position of the firn line on Hofsjökull. The sensors can be used together to locate some of the glacierfacies boundaries (Hall and Ormsby, 1983; Williams and others, 1991; Hall and others, 1995).

The ELA varied in the years 1994-98 between 1250 and $1410 \mathrm{~m}$ a.s.l. in northern Hofsjökull, and between 1150 and 1380 ma.s.l. in eastern Hofsjökull, according to massbalance measurements (Sigurðsson and Sigurðsson, 1998). The $\sigma^{\circ}$ boundary (corresponding to the approximate position of the firn line) was compared using digitally registered January ERS-1 or -2 data from 1994-98. Results showed that there was very little change in the position of this boundary in the 5 year period. However, a subtle increase in the elevation of this boundary occurred in the northern part of Hofsjökull from 1994 to 1997, but its position was stable between 1997 and 1998.

The accumulation-area ratio (AAR) is 0.55 according to measurements using the 13 August 1997 TM image (if the firn line and equilibrium line are approximately coincident at this time). The AAR of temperate glaciers that are in equilibrium is quite variable (Haeberli and others, 1999; personal communication from W. Haeberli, 1999). Only by measuring changes in the AAR over time will we be able to determine its significance for Hofsjökull. 

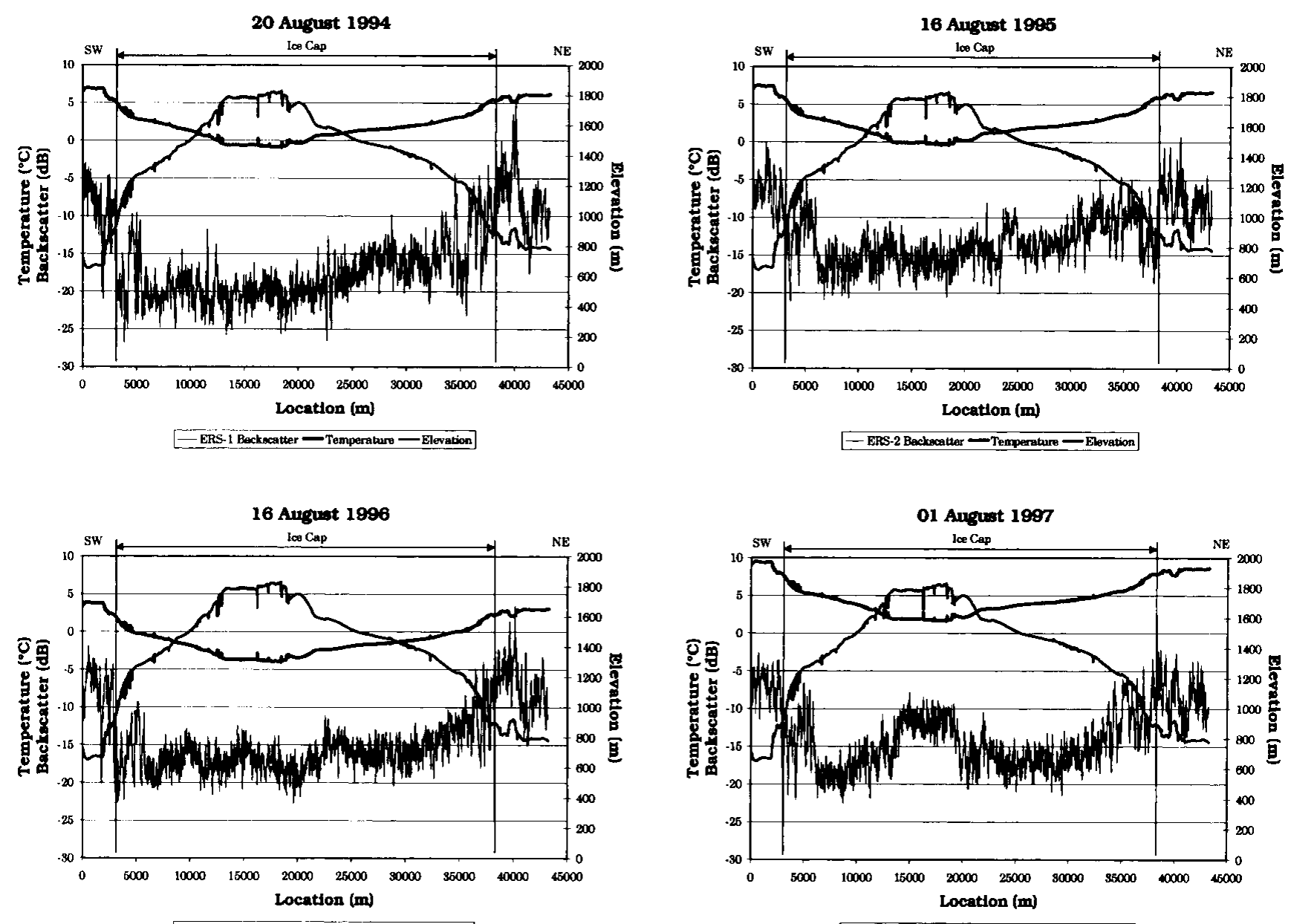

Fig. 9. August three-look $\sigma^{\circ}$ plotted along a transect ( $A-A^{\prime}$ ) ( see Fig. 5) of Hofsjökull, with elevation derived from the DEM and air temperature calculated from values reported at Hveravellir. Horizontal arrows at the top of each plot show the ice cap; the vertical lines show the ice-cap margins.

The ELA of Hofsjökull varied greatly in the years 199498 (Sigurðsson and Sigurðsson, 1998). In years of negative mass balance, the ELA is hard to detect in the wet-snow facies on the SAR images because it is obscured by newer firn with similar $\sigma^{\circ}$ characteristics, but may possibly be identified on TM images. $\sigma^{\circ}$ boundaries appearing on winter SAR images most probably represent the position of the firn line rather than the ELA (Hall and others, 1995). While there is a large difference between the position of the snowline from 19 August 1973 MSS and its position in the TM data from the 1990s, there was a heavy snowfall on Hofsjökull in mid-August 1973 which obliterated the latesummer snowline.

\section{Seasat SAR data of Hofsjökull}

A 24 August 1978 Seasat SAR image of Hofsjökull was acquired (from H. Rott and T. Nagler, Institut für Meteorologie und Geophysik, Innsbruck, Austria). Differential radar returns over the ice cap correspond to areas of wet snow in the accumulation area, and rough ice in the ablation area (Rott, 1984). However, due to the difference in wavelength of the sensors, an absolute comparison of the positions of the $\sigma^{\circ}$ boundaries in 1978 (Seasat) and in the 1990s (ERS) may not be prudent, and may not reveal an actual change in the position of the firn line on Hofsjökull.

\section{RADARSAT ScanSAR data of Hofsjökull}

Though uncalibrated, RADARSAT ScanSAR images of
Hofsjökull provide further insight into how rapidly changes in backscatter of a snow-covered glacier can occur. (ScanSAR images may be obtained more frequently than ERS images due to the different swath sizes.) Figure 12 (left) is a ScanSAR image acquired on 10 June 1997 at 0759 universal time (UT) (UT is the same as Iceland time). Figure 12 (right) is a ScanSAR image acquired 2 days later, on 12 June 1997 at 1832 UT. Table 2 shows the temperature and hours of sunshine for 6-13 June 1997 at the Hveravellir meteorological station. The temperature was $<0^{\circ} \mathrm{C}$ at Hveravellir until 9 June, after which it rose to $\sim 4^{\circ} \mathrm{C}$. Though the average air temperatures were similar on 10 and 12 June, there were more hours of sunshine on 12 June. It is interesting to note the ridge

Table 2. Temperature and hours of sunshine at Hveravellir

$$
\text { Day (June 1997) Temperature Hours of sunshine }
$$

${ }^{\circ} \mathrm{C}$

\begin{tabular}{ccc}
\hline 6 & -1.0 & \\
7 & -3.7 & 9.7 \\
8 & -1.4 & 3.6 \\
9 & 4.0 & 0.5 \\
10 & 3.0 & 11.7 \\
11 & 4.3 & 2.7 \\
12 & 3.4 & 9.8 \\
13 & 4.4 & 6.0 \\
& & 5.4 \\
\hline
\end{tabular}

Source: M. M. Magnússon, Icelandic Meteorological Service. 

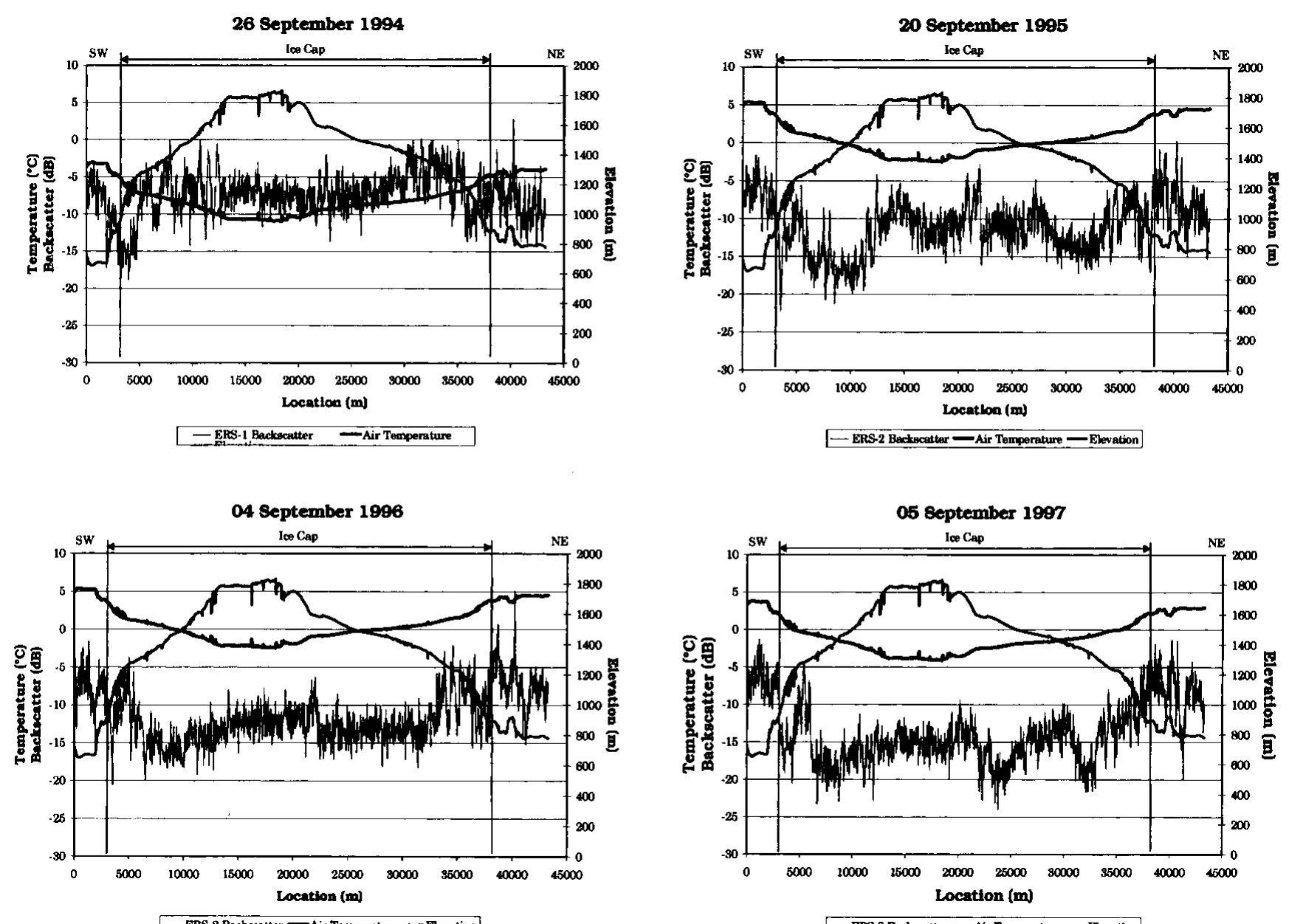

Fig. 10. September three-look $\sigma^{\circ}$ plotted along a transect $\left(A-A^{\prime}\right)$ ( see Fig. 5) of Hofsjökull, with elevation derived from the DEM and air temperature calculated from values reported at Hveravellir. Horizontal arrows at the top of each plot show the ice cap; the vertical lines show the ice-cap margins.

(Miklafell) in the northeastern part of Hofsjökull as shown in Figure 12 (see also Fig. 2 for the location of Miklafell). ScanSAR returns on 10 June probably are higher around and along the ridge than they are on 12 June due to the enhanced melting on 12 June. The 10 June image was acquired early in the morning, and the 12 June image early in the evening. This is likely to accentuate the decrease in the SAR returns on 12 June by allowing more melting during the daytime. This ScanSAR pair, along with the DEM, further demonstrates the important effect that elevation has on the snow state and thus the SAR returns.

The fact that the 10 June image came from an ascending orbit and the 12 June image from a descending orbit does complicate the analysis. Areas of the glacier that slope away from the satellite in the first image slope towards the satellite in the second image, so the magnitude of the radar returns on the ascending and descending images may not be comparable.

\section{SUMMARY AND CONGLUSIONS}

Using 57 ERS-1 or -2 SAR images, a Seasat SAR image, Landsat images and RADARSAT ScanSAR images, the position of the late-summer snowline (firn line), glacier area and surficial changes in Hofsjökull ice cap are studied. We measured the approximate position of the presumed firn line each January from 1994 to 1998 using ERS-1 and -2 SAR data. Results show that the boundary is very stable during the
5 years, though a small increase in elevation was observed between 1994 and 1997 in the northern part of the ice cap.

The $\sigma^{\circ}$ boundary representing the firn line is apparently much more strongly represented in the SAR winter images than is the equilibrium line of the previous year, if the firn line from a previous year lies below the equilibrium line. Thus the equilibrium line may be obscured by firn lines from previous years.

A DEM was constructed using SAR interferometry and ancillary information, thus allowing us to quantify changes in the state of snow- and firn-based and air temperature, and to plot the backscatter. The InSAR DEM was compared quantitatively with a DEM that was digitized from a UISI topographic map. The elevations calculated from the InSAR DEM were within $\pm 75 \mathrm{~m}$ of the UISI elevations except in areas where misregistration of the two DEMs occurs, and in areas where radar layover effects are pronounced.

Four SAR $\sigma^{\circ}$ regimes are identified and appear to be consistent from year to year, although variation in air temperature causes $\sigma^{\circ}$ changes on different dates each year. The winter $\sigma^{\circ}$ regime consists of relatively high and uniform $\sigma^{\circ}$ (e.g. approximately -5 to $5 \mathrm{~dB}$ ), followed by a spring transitional regime when $\sigma^{\circ}$ drops due to surficial melt, first at lower elevations, then at higher elevations. During the summer $\sigma^{\circ}$ regime, surficial melt causes very low $\sigma^{\circ}$ (down to $-25 \mathrm{~dB}$ or lower) in the wet-snow and percolation facies where the surface snow and firn is wet. Also in summer, the $\sigma^{\circ}$ is higher in the ablation area than in the accumulation area because the rough ice surface comprising the ablation 


\section{TM 13 August 1997}

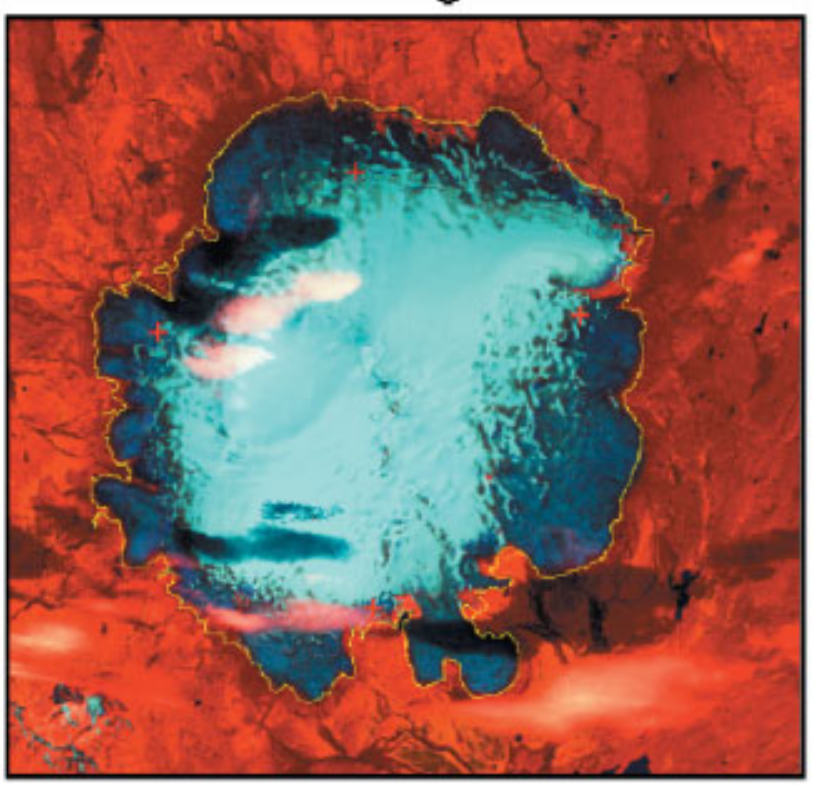

\section{ERS-2 05 September 1997}

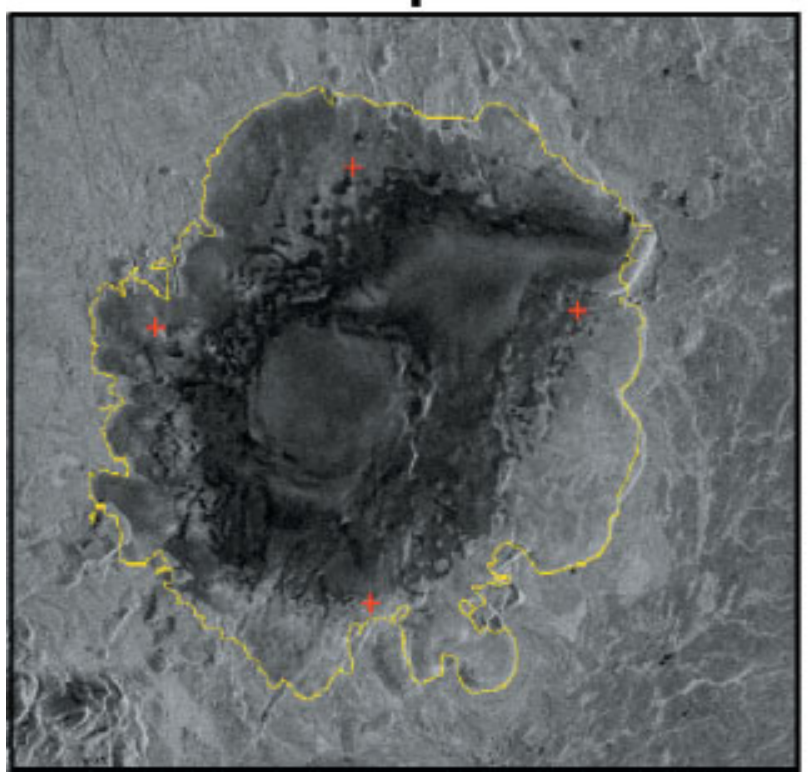

ERS-2 07 January 1998

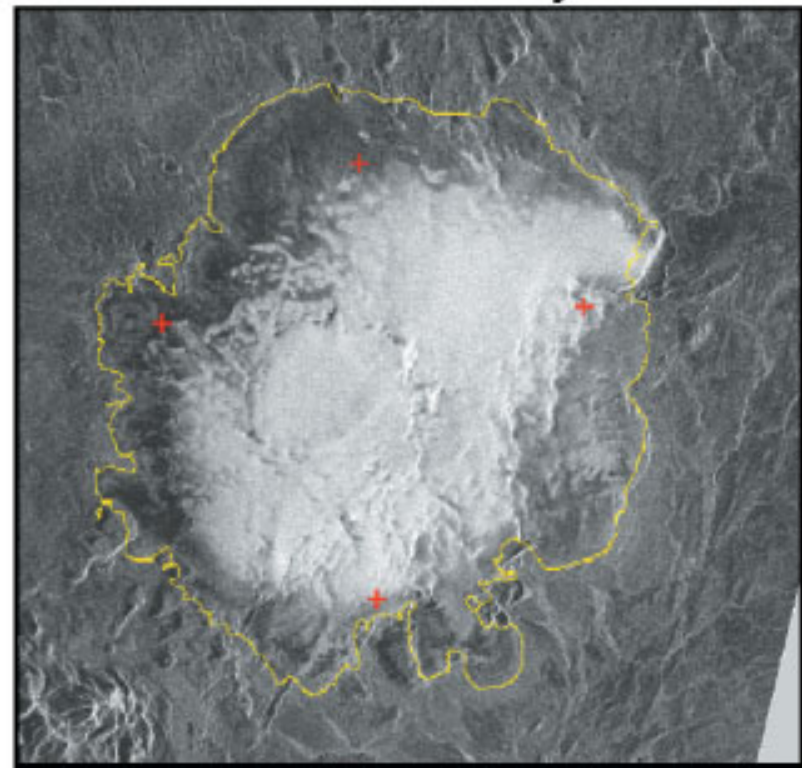

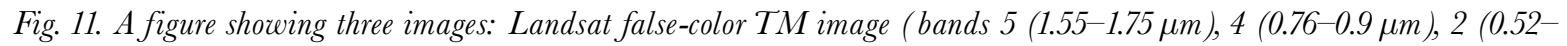
$0.6 \mu \mathrm{m}$ )) acquired on 13 August 1997 (scene i.d. No. 52180150097225, path/row 218/15) and two ERS-2 SAR images acquired on 5 September 1997 and 7 January 1998, respectively, of Hofsjökull. The yellow line shows the outline of the ice-cap margin determined from the 19 August 1973 MSS image (Fig. 3). The four red plus signs are placed to show the correspondence of the low $\sigma^{\circ}$ parts of the ERS-2 images with the high-reflectance parts of the TM image. The scenes are digitally registered, and the plus signs are in exactly the same place on all of the images. (Approximately 100 "control points", points in common between the TM and SAR images, were used to register the scenes.) The boundaries of the low-backscatter/high-reflectance areas are thought to correspond roughly to the firn line. The $\sigma^{\circ}$ boundary in the January image is presumed to be the firn line. The radar look direction is shown by the arrow in the upper left part of each SAR image. (C) ESA.

area causes scattering of the microwave signal. In the fall transitional regime, freeze-up is observed when the air temperature drops below $0^{\circ}$ to $-5^{\circ} \mathrm{C}$, first at the higher elevations, and then at the lower elevations. The air-temperature drop is associated with an increase in $\sigma^{\circ}$ because volume scattering from the wet-snow and percolation facies occurs after the snow and firn refreezes. In this study, we have found that when the air temperature fluctuates from $-5^{\circ}$ to $0^{\circ} \mathrm{C}$, sudden $\sigma^{\circ}$ changes can occur.

Comparison of late-summer 1997 TM and ERS-2 images reveals that the high-reflectance and low- $\sigma^{\circ}$ parts of the ice cap generally correspond extremely well; the location of the presumed firn line is very similar on both summer images. Furthermore, the $\sigma^{\circ}$ boundary on ERS-2 data from the following winter shows that the firn line is still visible even though the ice cap is covered with snow. This same pattern was also noted on 1995 summer TM and SAR data, and January 1996 SAR data.

Only small changes in the ice-front margin of Hofsjökull were found from 1973 to 1997, except on the outlet glacier, Djórsárjökull, where an advance was measured. Because Landsat often presents a better contrast between a glacier and the surrounding moraine, Landsat images are generally more useful for measuring glacier area than are SAR images.

RADARSAT ScanSAR images, acquired in June 1997, 
10 June 1997

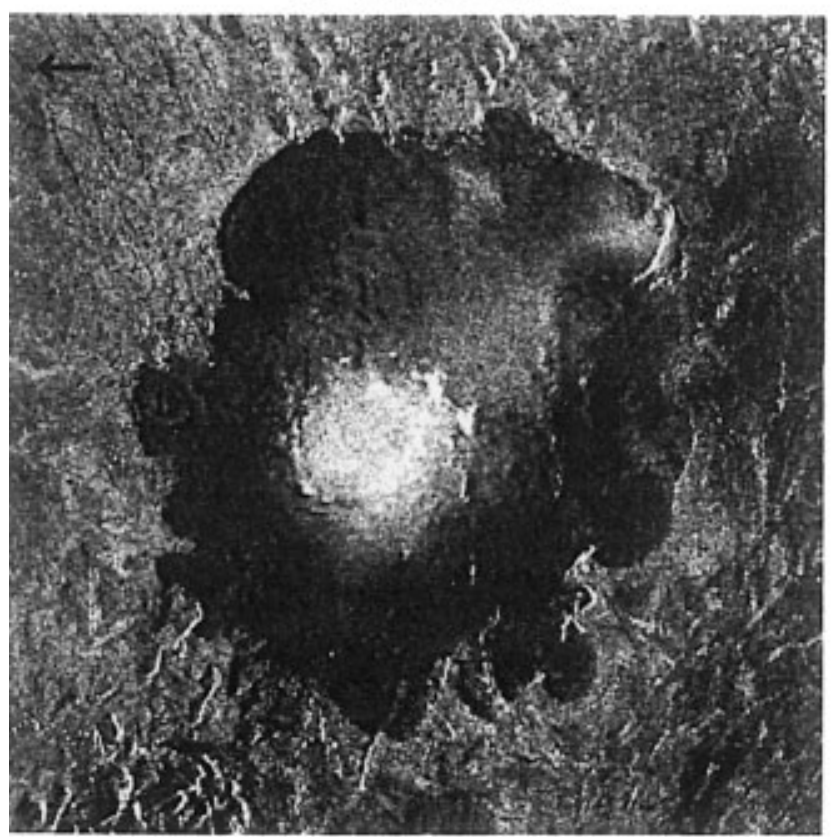

12 June 1997

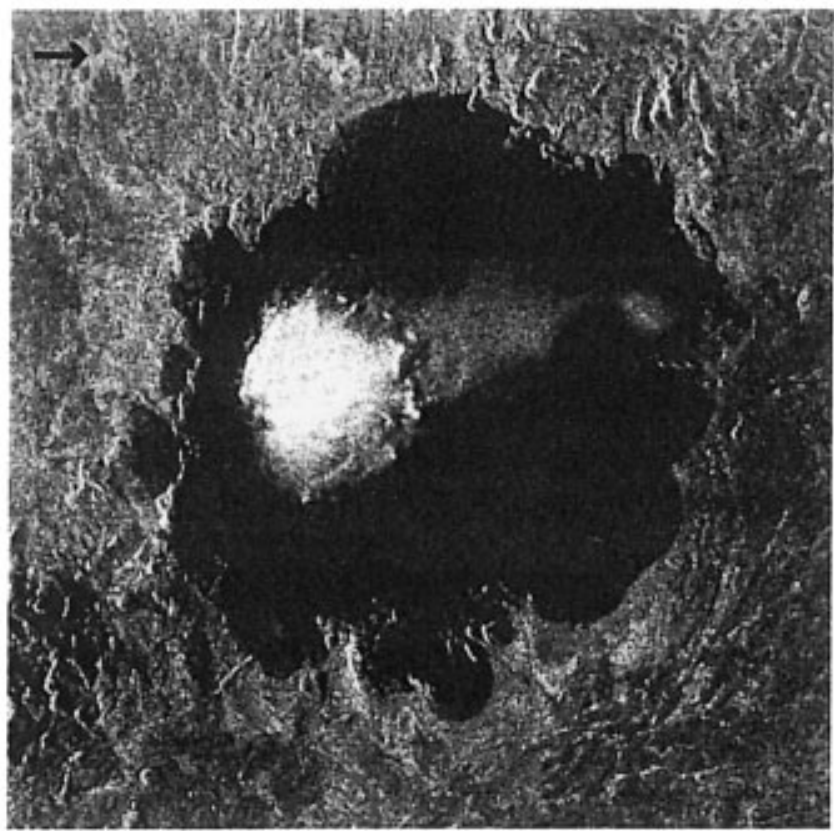

Fig. 12. RADARSAT ScanSAR wide-swath B image of Hofsjökull (R108343287G3S004) acquired on 107 June 1997 at 0759

UT shown on the left (ascending orbit); RADARSAT ScanSAR wide-swath B image of Hofsjökull (R108378163G3S003) acquired on 12 June 1997 at 1832 UT shown on the right (descending orbit). The radar look direction is shown by the arrow in the upper left part of each image. (C) CSA.

show $\sigma^{\circ}$ decreases which follow from the general warming and melting of the surface of the ice cap, especially at the lower elevations. $\sigma^{\circ}$ decreases are especially evident on and near Miklafell, a ridge in the northeastern part of Hofsjökull, from 10 to 12 June 1997, as seen on the ScanSAR images.

In conclusion, $\mathrm{SAR} \sigma^{\circ}$ changes are shown to be closely tied to elevation and air temperature on Hofsjökull. The position of the firn line can be measured on both Landsat and SAR imagery, but new snowfall may obscure the firn line on Landsat imagery. Near the end of the melt season in 1997, the late-summer snowline occurs at $\sim 1000 \mathrm{~m}$ a.s.l. in the eastern part, and $\sim 1300 \mathrm{~m}$ in the western part of the ice cap, where the average air temperature was approximately $-3^{\circ}$ and $-5^{\circ} \mathrm{C}$, respectively. The location of the SAR $\sigma^{\circ}$ boundary representing the presumed firn line is shown to be stable on the five available January ERS-1 or -2 SAR images that were studied, even though the ELA varied significantly, according to ground measurements.

\section{ACKNOWLEDGEMENTS}

The authors would like to thank J.Y. L. Chien of General Sciences Corporation, Lanham, Maryland, for her expertise in image processing; C. Werner of Gamma Remote Sensing for technical help regarding interferometric processing; D. Alsdorf of the Institute for Computational Earth System Sciences at the University of California Santa Barbara for discussions concerning the construction of the Hofsjökull DEM using interferometry; M. M. Magnússon and G. Gísladóttir of the Icelandic Meteorological Service for meteorological data from Hveravellir; and H. Rott and T. Nagler for their generosity in providing us with the digital Seasat SAR data. We would also like to acknowledge the ESA for providing ERS-1/2 SAR data, and the Alaska SAR Facility for providing the RADARSATdata.

\section{REFERENCES}

Barton, J. S., D. K. Hall, O. Sigurðsson, R. S. Williams, Jr, L. C. Smith and J. B. Garvin. 2000. Calculation and analysis of an interferometric digital elevation model of Hofsjökull, Iceland. Proc. East. Snow Conf., 56th Annual Meeting, 2-4 June 1999, Fredericton, New Brunswick, Canada, 5-12.

Benson, C. S. 1962. Stratigraphic studies in the snow and firn of the Greenland ice sheet. SIPRE Res. Rep. 70.

Benson, C. S. 1996. Stratigraphic studies in the snow and firn of the Greenland ice sheet. SIPRE Res. Rep. 70. [Revised edition of 1962 report.]

Bindschadler, R. A. and P. L. Vornberger. 1992. Interpretation of SAR imagery of the Greenland ice sheet using coregistered TM imagery. Remote Sensing Environ., 42(3), 167-175.

Björnsson, H. 1980a. Glaciers in Iceland. Fökull, 29, 1979, 74-80.

Björnsson, H. 1980b. The surface area of glaciers in Iceland. Fökull, 28, 1978, 31.

Björnsson, H. 1986. Surface and bedrock topography of ice caps in Iceland, mapped by radio echo-sounding. Ann. Glaciol., 8, 11-18.

Björnsson, H. 1988. Hydrology of ice caps in volcanic regions. Visindafélag Ísl. Rit. 45.

Brown, I. A., M. P. Kirkbride and R. A. Vaughan. 1999. Find the firn line! The suitability of ERS-1 and ERS-2 SAR data for the analysis of glacier facies on Icelandic icecaps. Int. 7. Remote Sensing, 20 (15-16), 3217-3230.

Crabtree, R. D. 1976. Changes in Mýrdalsjökull ice cap, south Iceland: possible uses of satellite imagery. Polar Rec., 18(112), 73-76.

Fahnestock, M., R. Bindschadler, R. Kwok and K. Jezek. 1993. Greenland ice sheet surface properties and ice dynamics from ERS-1 SAR imagery. Science, 262(5139), 1530-1534.

Forster, R. R., B.L. Isacks and S. B. Das. 1996. Shuttle imaging radar (SIRC/X-SAR) reveals near-surface properties of the South Patagonian icefield. f. Geophys. Res., 101(E10), 23,169-23,180.

Forster, R. R., L. C. Smith and B. L. Isacks. 1997. Effects of weather events on X-SAR returns from ice fields: case-study of Hielo Patagónico Sur, South America. Ann. Glaciol., 24, 367-374.

Goldstein, R. M., H. A. Zebker and C. L. Werner. 1988. Satellite radar interferometry: two-dimensional phase unwrapping. Radio Sci., 23(4), 713-720.

Goldstein, R. M., H. Engelhardt, B. Kamb and R. M. Frolich. 1993. Satellite radar interferometry for monitoring ice sheet motion: application to an Antarctic ice stream. Science, 262(5139), 1525-1530.

Haeberli, W., M. Hoelzle and R. Frauenfelder, eds. 1999. Glacier Mass Balance Bulletin. Bulletin No. 5 (1996-1997). Zürich, IAHS(ICSI), World Glacier Monitoring Service; Nairobi, UNEP; Paris, UNESCO.

Hall, D. K. and J. P. Ormsby. 1983. Use of SEASAT synthetic aperature radar and LANDSAT multispectral scanner subsystem data for Alaskan glaciology studies. 7. Geophys. Res., 88(C3), 1597-1607.

Hall, D. K., R. S. Williams, Jr and K. J. Bayr. 1992. Glacier recession in Iceland and Austria as observed from space. EOS, 73(12), 129, 135, 141. 
Hall, D. K., R. S. Williams, Jr and O. Sigurðsson. 1995. Glaciological observations of Brúarjökull, Iceland, using synthetic aperture radar and thematic mapper satellite data. Ann. Glaciol., 21, 271-276.

Jóhannesson, T. 1997. The response of two Icelandic glaciers to climatic warming computed with a degree-day glacier mass-balance model coupled to a dynamic glacier model. f. Glaciol., 43(144), 321-327.

Jóhannesson, T. and O. Sigurðsson. 1998. Interpretation of glacier variations in Iceland 1930-1995. Fökull, 45, 27-33.

Joughin, I., D. Winebrenner, M. Fahnestock, R. Kwok and W. Krabill. 1996. Measurement of ice-sheet topography using satellite-radar interferometry. f. Glaciol., 42(140), 10-22.

Joughin, I. R., R. Kwok and M. A. Fahnestock. 1998. Interferometric estimation of three-dimensional ice-flow using ascending and descending passes. IEEE Trans. Geosci. Remote Sensing, GE-36(1), 25-37.

Laur, H., P. Bally, P. Meadows, J. Sanchez, B. Schaettler and E. Lopinto. 1997. ERS SAR calibration: derivation of the backscattering coefficient $\sigma^{\circ}$ in ESA SAR PRI products. Fourth edition. Noordwijk, European Space Agency. (ESA/ERIN Tech. Note 2; ES-TN-RS-PM-HL09, Rev. 4.)

Lingle, C. S., W. D. Harrison and K. Ahlnäs. 1992. Observations of glaciers in the St. Elias Mountains, Alaska-YukonTerritory, with synthetic aperture radar. Abstract. In Environmental Change: Natural and Man-Made. AAAS 43rd Arctic Science Conference, 8-12 September 1992, Valdez, Alaska. Program and Proceedings. Fairbanks, AK, University of Alaska. Geophysical Institute, 387.

Lingle, C. S., D. R. Fatland, V. Voronina, K. Ahlnäs and E. Troshina. 1997. Dynamic behaviour of the Bering Glacier-Bagley Ice Field system during a surge, and other measurements of Alaskan glaciers with ERS imagery. In Third ERS Scientific Symposium, 17-21 March 1997, Florence, Italy. Proceedings. Frascati, Italy, European Space Agency, 995-1000. (ESA Publication SP-414.)

Mattar, K. E., P.W. Vachon, D. Geudtner, A. L. Gray, I. G. Cumming and M. Brugman. 1998. Validation of alpine glacier velocity measurements using ERS tandem-mission SAR data. IEEE Trans. Geosci. Remote Sensing, GE-36(3), 974-984.

Mätzler, C. and E. Schanda. 1984. Snow mapping with active microwave sensors. Int. 7. Remote Sensing, 5(2), 409-422.

Meadows, J., H. Lauer and B. Schatler. 1998. The calibration of ERS SAR imagery for land applications. In 2nd International Workshop on Retrieval of Bio- and Geo-physical Parameters from SAR Data for Land Applications, 21-23 October 1998, Noordwijk. Proceedings. Noordwijk, European Space Agency, 35-42. (ESA SP-441.)

Partington, K. C. 1998. Discrimination of glacier facies using multi-temporal SAR data. 7. Glaciol., 44(146), 42-53.

Paterson, W. S. B. 1994. The physics of glaciers. Third edition. Oxford, etc., Elsevier

Proud, L. and B. Battrick, eds. 1998. The ERS-1 user handbook. Noordwijk, European Space Agency. ESTEC Division.

Ramage, J. M., B. L. Isacks and M. M. Miller. 2000. Radar glacier zones in southeast Alaska, U.S.A.: field and satellite observations. f. Glaciol.,
46(153), 287-296.

Raney, R. K. 1998. Radar fundamentals: technical perspectives. In Henderson, F. M. and A. J. Lewis, eds. Principles and applications of imaging radar. Manual of remote sensing. New York, John Wiley and Sons Inc., 9-130.

Rees, W. G., J. A. Dowdeswell and A. D. Diament. 1995. Analysis of ERS-1 synthetic aperture radar data from Nordaustlandet, Svalbard. Int. 7. Remote Sensing, 16 (5), 905-924.

Rignot, E. 1995. Backscatter model for the unusual radar properties of the Greenland ice sheet. 7. Geophys. Res., 100(E5), 9389-9400.

Rignot, E., R. Forster and B. Isacks. 1996. Interferometric radar observations of Glaciar San Rafael, Chile. F. Glaciol., 42(141), 279-291; Erratum $42(142), 591$.

Rott, H. 1984. Synthetic aperture radar capabilities for snow and glacier monitoring. Adv. Space Res., 4(11), 241-246.

Sigfúsdóttir, A. B. 1964. Nedbör og temperatur i Island. In Islands hydrologi. Reykjavík, Raforkumálastjóri, 112.1-112.17. (4 Nordiske Hydrologkonferanse.)

Sigurðsson, O. andT. Jónsson. 1995. Relation of glacier variations to climate changes in Iceland. Ann. Glaciol., 21, 263-270.

Sigurðsson, O. and Ó. J. Sigurðsson. 1998. Afkoma nokkura jökla á Íslands 1992-1997. Reykjavík, Orkustofnun (National Energy Authority). (Report OS-98082.)

Sigurðsson, O. and R. S. Williams, Jr. 1998. Past, present and future glacier fluctuations in Iceland: an environmental response to climatic variability in the North Atlantic. In Abstracts and curriculum vitae of International Workshop on Environmental and Climatic Variations in the North Atlantic Region, 23-26 September 1998, Reykjavik, Iceland. Reykjavík, Icelandic Research Council. European Commission. National Science Foundation, 29.

Smith, L. C., R. R. Forster, B. L. Isacks and D. K. Hall. 1997. Seasonal climatic forcing of alpine glaciers revealed with orbital synthetic aperture radar. $\mathcal{F}$. Glaciol., 43(145), 480-488.

Pórarinsson, S. 1974. Sambúð lands og lýðs í ellefu aldir. In Líndal, S., ed. Saga Íslands I. Reykjavík, Hið Íslenska Bókmentafélag. Sögufélagið, 29-97.

Williams, R. S., Jr. 1983. Satellite glaciology of Iceland. Fökull, 33, 3-12.

Williams, R. S., Jr. 1987. Satellite remote sensing of Vatnajökull, Iceland. Ann. Glaciol., 9, 127-135.

Williams, R. S., Jr, S. Thórarinsson, H. Björnsson and B. Gudmundsson. 1979. Dynamics of Icelandic ice caps and outlet glaciers. [Abstract.] $\mathcal{F}$. Glaciol., 24(90), 505-507.

Williams, R. S., Jr, D. K. Hall and C. S. Benson. 1991. Analysis of glacier facies using satellite techniques. F. Glaciol., 37(125), 120-128.

Williams, R. S., Jr, D. K. Hall, O. Sigurðsson and J.Y. L. Chien. 1997. Comparison of satellite-derived with ground-based measurements of the fluctuations of the margins of Vatnajökull, Iceland, 1973-92. Ann. Glaciol., 24, 72-80.

Zebker, H. A., C. L. Werner, P. A. Rosen and S. Hensley. 1994. Accuracy of topographic maps derived from ERS-1 interferometry. IEEE Trans. Geosci. Remote Sensing, GE-32(4), 823-836. 